\title{
Translating English WOMAN IS AN ANIMAL metaphors: Spanish native speakers' associations with novel metaphors
}

\author{
Kristina Fernandes (Vienna)
}

\begin{abstract}
Animal metaphors are prevalent across languages and convey a variety of, oftentimes negative, meanings - more so for women than men. In English, for example, both lion and lioness refer to a sexually active, dominant man or woman respectively, but while the former is endowed with positive connotations (courage, strength), the latter evokes negative associations (danger, voracity). There are some animal terms, however, that do not feature in animal metaphors in a certain language, posing the question as to which associations are evoked by those animal terms that are not part of conventional animal metaphors. This paper explores Spanish speakers' interpretations of mappings of the WOMAN IS AN ANIMAL metaphor that are documented to exist in English but not in Spanish. This was tested with two online questionnaires, one employing open questions and the other one Likert scales presenting possible traits (e. g. quarrelsome, kind, promiscuous), in which Spanish speakers had to judge the animal metaphors which were translated from English. The results show that the novel animal metaphors are mainly associated by Spanish native speakers with negative features, first and foremost with ugliness. Additionally, most of the animal terms convey different meanings in English and Spanish. For example, musaraña, the Spanish equivalent of shrew, is not associated with bad temper and quarrelling, but instead with ugliness and muddleheadedness. Furthermore, the findings reveal significant insecurities in the interpretation of the translated metaphors by the Spanish speakers. These results might be an indication for both the arbitrariness and the stableness of associations with different animal species, depending on the speakers' culture. It also seems that novel animal metaphors mainly provide mental access to unattractiveness as it is a concrete physical feature and might therefore be more accessible than abstract personality traits such as kindness or quarrelsomeness.
\end{abstract}

\section{$1 \quad$ Introduction}

It has long been argued by cognitive linguists that metaphor is not just a figure of speech for the purpose of embellishing language but instead is integral to human thinking (cf. Lakoff/Johnson 1980, 1999; Kövecses 2000; Deignan 2010). Thus, through metaphor, humans conceptualize one concept (target) in terms of another concept (source). Examples of such conceptualizations include the metaphors ARGUMENT IS WAR, LOVE IS A JOURNEY (cf. Lakoff/Johnson 1980), and PEOPLE ARE ANIMALS (cf. Kövecses 2010: 153). English examples of the latter conceptual metaphor are chick and cow to refer to a young and coarse woman respectively, as well as wolf 
and lion denoting a sexually aggressive and notable man respectively. These examples highlight the role that the PEOPLE ARE ANIMALS metaphor can play in reinforcing gender stereotypes by likening women and men to different types of animals.

While animal metaphors can be considered universal as they are likely prevalent in all languages (cf. Kövecses 2005: 25), the associations conveyed by the animal terms can sometimes vary greatly between languages. For example, both rabbit and the Spanish equivalent coneja refer to a woman who has given birth to many children, but in another English/Spanish pair, namely bird and pájara, the associations differ greatly: Bird is used affectionately in English to denote a girl or young woman, whereas the Spanish equivalent pájara refers to a cunning woman or a prostitute (cf. López-Rodríguez 2009: 88). Such variations are due to cultural differences between the speakers of different languages, with culture serving as a filter:

While the body is a potentially universal source for emerging metaphors, culture functions as a filter that selects aspects of sensorimotor experience and connects them with subjective experiences and judgments for metaphorical mappings. That is, metaphors are grounded in bodily experience but shaped by cultural understanding.

(Yu 2008: 247)

Animal metaphors are "pre-established by a long tradition" (Bisschops 2019: 1) so the associations that they convey are rather stable. However, in each language only a certain, although large set of animal species features in animal metaphors. This poses the question as to which associations are evoked by animal terms that are not part of conventional animal metaphors in a given language. Contrastive studies have generally focussed on the comparison of animal metaphors that are documented to exist in the respective studied languages (cf. Fernández Fontecha/Jiménez Catalán 2003; Reza Talebinejad/Vahid Dastjerdi 2005; Hsieh 2006; LópezRodríguez 2009). However, it is the goal of the present study to explore the extent to which the associations conveyed by conventional animal metaphors in one language (English) correspond to those conveyed by novel animal metaphors in another language (Spanish) when they are not fixed by tradition. Thus, the present study tests Spanish speakers' judgements about mappings of the WOMAN IS AN ANIMAL metaphor that are documented in English but not in Spanish. For example, the English animal term shrew is conventionally used to denote an ill-tempered, quarrelsome woman, whereas the Spanish equivalent musaraña is not documented to be used in mappings of the WOMAN IS AN ANIMAL metaphor.

So far, research on animal metaphors has had various foci. There have been contrastive studies (cf. Nesi 1995), cognitive linguistic analyses (cf. Sanz Martin 2015), combinations of those two approaches (cf. Fernández Fontecha/Jiménez Catalán 2003), studies on the translation of animal metaphors (cf. Dobrotă 2017), diachronic analyses (cf. López-Rodríguez 2014), and studies on the behavioural impact that animal metaphors can have (cf. Bock/Burkley 2018). However, to the author's knowledge, no study has yet tested speakers' associations with animal metaphors that are not documented in the speakers' native language but in another language. It is the goal of the present study to contribute to filling this research gap. For that, using English dictionaries (The Oxford English Dictionary (OED), The Oxford Dictionary of Modern Slang (Ayto/Simpson 2013), etc.), English animal terms referring to different types of women (e. g. promiscuous woman, old woman, good-looking woman) were collected which are not documented to exist in Spanish. Then, in two separate online questionnaires, native speakers of Spanish judged the 
translated animal metaphors in terms of their meaning. In the first one, participants rated the animal metaphors on Likert scales, whereas the second questionnaire employed open questions, allowing for a multi-methodological approach to detect Spanish speakers' associations with undocumented animal metaphors. Accordingly, participants appear to be more unsure about the meanings of animal metaphors when confronted with open questions compared to when being able to choose from several options on Likert scales.

The present study, thus, aims to contribute to the contrastive investigation of animal metaphors by researching animal metaphors that are novel in one language, instead of comparing animal metaphors that are established in both languages as has been the focus of many previous studies. This approach should help shed light on native speakers' associations with certain animal species when they are not conventional source concepts in the WOMAN IS AN ANIMAL metaphor.

In the following, the theoretical framework of this study is outlined, which comprises Cognitive Metaphor Theory followed by an overview of the research that has been done on animal metaphor. Next, the methodology employed for the creation and analysis of the questionnaires is introduced, and finally, the results obtained from the two questionnaires are presented and discussed.

\section{$2 \quad$ Theoretical framework}

\subsection{Metaphor in Cognitive Linguistics}

According to cognitive linguists, metaphor is more than simply a figure of speech. Instead, it is fundamental to human thought and cognition (cf. Lakoff/Johnson 1980, 1999; Kövecses 2000; Deignan 2010). Metaphor is "understanding and experiencing one kind of thing in terms of another" (Lakoff/Johnson 1980: 5), meaning that, through metaphor, a target domain is conceptualized in terms of a source domain. This correspondence between the two domains is understood of as conceptual mapping. The following sentences highlight a well-known example of metaphor, namely the ARGUMENT IS WAR metaphor in which a mapping occurs from the source domain WAR to the target domain ARGUMENT (cf. Lakoff/Johnson 1980: 4):

(1) I've never won an argument with him.

(2) He attacked every weak point in my argument.

(3) Your claims are indefensible.

As Lakoff/Johnson (1980) state, "we don’t just talk about arguments in terms of war [...] [but] the ARGUMENT IS WAR metaphor is one that we live by in this culture: it structures the actions we perform in arguing" (ibd.: 4).

When a target domain is conceptualized in terms of a source domain, certain aspects of the target are highlighted while others remain hidden. The ARGUMENT IS WAR metaphor, for example, "highlights the adversarial nature of argument but hides the fact that argument often involves an ordered and organized development of a particular topic" (Evans/Green 2006: 304). Furthermore, it is important to note that metaphors are unidirectional, meaning that structures are mapped from the source to the target domain but not the other way around, even when two different metaphors share two domains, such as PEOPLE ARE MACHINES and MACHINES ARE 
PEOPLE. In other words, when conceptualizing people as machines, different structures are mapped than when conceptualizing machines as people (cf. Lakoff/Turner 1989: 132).

While metaphor research mostly focuses on the conceptualization of the abstract in terms of the concrete - as is the case with many frequently discussed metaphors such as TIME IS MONEY, ARGUMENT IS WAR, LOVE IS A JOURNEY, and THEORIES ARE BUILDINGS (cf. Lakoff/Johnson 1980) - it is important to note that the target domains can be concrete, too: "[M]etaphorical mappings do not always involve abstract targets, as the source domain is not always more accessible to sense perception or closer to our everyday experience than the target domain" (Crespo-Fernández 2015: 23; cf. also Forceville 2006: 387). An example of a concrete-to-concrete mapping is the PEOPLE ARE ANIMALS metaphor which is at the core of the present study (see 2.2).

An important distinction when talking about metaphor regards conventionality and novelty. The Conceptual Mapping Model (cf. Ahrens 2010) distinguishes between four types of metaphor, from most conventional to most novel:

(a) Conventional metaphors that are common in the language, e. g. NEGATIVE PAST EMOTIONS AND MEMORIES ARE BAGGAGE.

(1) I need to get rid of this emotional baggage. (cf. Cameron/Deignan 2006: 678-680)

(b) Novel metaphors that follow the mapping principle but are novel usages. They require the activation of an underlying connection.

(2) I need to get rid of this emotional luggage.

(c) Novel metaphors that do not follow the mapping principle. They require the listener to make a new connection between the source and the target.

(3) I need to get rid of this emotional handbag.

(d) Anomalous metaphors, i. e. novel metaphors that use a source-target domain pairing that never occurs in the language, e. g. ECONOMY IS FOOD.

(4) The two sides are digesting natural resources. (cf. Ahrens et al. 2007: 164)

While previous research has only distinguished between conventional and novel metaphors, Ahrens (2010) has shown in on-line and off-line psycholinguistic experiments that there are indeed differences in terms of metaphoric understanding between all four types of metaphor (a-d). Accordingly, declining conventionality and increasing novelty equal a decline in metaphor acceptability and interpretability. For that reason, it is important to distinguish between the different types of metaphors one is dealing with.

It has long been argued by cognitive scientists that metaphors which originate from human physiology and embodied experiences are universal (cf. Neumann 2001: 124; Kövecses 2005: 3; Evans/Green 2006: 308). For example, the metaphor AFFECTION IS WARMTH (cf. Kövecses 1986: 101) - which is based on "the correlation in our childhood experiences between the loving embrace of our parents and the comforting bodily warmth that accompanies it" (Kövecses 2005: 2f.) - exists in many languages and can be considered a universal metaphor. However, in metaphor research, emphasis has also been put on the cultural and contextual nature of metaphor. This approach, which distinguishes between cross-cultural and within-culture variation, is described by Kövecses (2008) as a cultural-cognitive theory of metaphor. For example, the metaphor HAPPINESS IS FLOWERS IN THE HEART exists in Chinese, but not in English, whereas the English metaphor BEING HAPPY IS BEING OFF THE GROUND does not exist in Chinese (cf. 
Kövecses 2008: 60). One metaphor that can be considered universal while at the same time highly depending on culture and context is the PEOPLE ARE ANIMALS metaphor. ${ }^{1}$

\subsection{The PEOPLE ARE ANIMALS metaphor}

When dealing with the PEOPLE ARE ANIMALS metaphor, the question arises how it happens that animals are used to talk about humans and human behaviour. As Kövecses (2010: 152) states, animals do not inherently possess human qualities. Instead, humans ascribe human characteristics to animals, thus personifying them, before reapplying them to humans, hence animalizing them. For example, a female dog is not spiteful per se, but humans attribute spitefulness to female dogs and apply it to a woman when referring to her as bitch.

In order to make sense of the conceptualization of humans as animals, it is essential to consider the so-called Great Chain of Being (cf. Lakoff/Turner 1989). This cultural folk model places humans, animals, plants and inanimate objects on a vertical hierarchy, representing the supposed world order of "higher" versus "lower" entities. Accordingly, the lowest entity are inanimate objects, which are nothing but substance, while plants additionally have life. Animals have all these properties, but they also show animal behaviour such as instincts. Lastly, on top of all these properties, humans also have human-specific attributes such as reason, morality, and consciousness. However, each level contains further sublevels, so while they are both inanimate objects, a chair is more complex than a stone, and while they are both animals, a cat is more complex than a bug, for example (cf. Lakoff/Turner 1989: 167f.). Furthermore, sublevels also exist within the category of humans. Accordingly, "men rank above women because traditionally the former are believed to be ruled by reason whereas the latter by their heart, which seems to bring the female sex closer to the animal kingdom" (López-Rodríguez 2016: 94; cf. also Fernández Fontecha/Jiménez Catalán 2003: 794). When referring to a human as an animal - as is the case in the PEOPLE ARE ANIMALS metaphor - the target HUMAN is downgraded to a member of the lower category ANIMAL, hence depriving the person of their human-specific characteristics (cf. López-Rodríguez 2016: 77; Tipler/Ruscher 2019: 110).

However, as Haslam/Loughnan/Sun (2011) have shown, animal metaphors are not always inherently offensive. Instead, there are factors that contribute to the offensiveness of animal metaphors while others mitigate it:

Offensiveness derives both from the transfer of reviled characteristics from taboo animals to metaphor targets and from the positioning of the target as literally less than human, even when the animal in question is not taboo. [...] It may be possible to distinguish two kinds of offensive animal metaphors: those that are disgusting and those that are degrading.

(ibd.: 318)

Furthermore, the context of the animal metaphor plays a crucial role in its offensiveness. It seems that offensiveness is greater when the metaphor is used in a hostile manner addressed to women and in intergroup contexts, especially when referring to someone's appearance (cf. ibd.: 322). In any case, "animal metaphors may be insulting in part because they are - or are intended to be - dehumanizing" (ibd.: 312).

\footnotetext{
1 While the PEOPLE ARE ANIMALS metaphor is largely considered a universal metaphor, there are some indigenous languages in which the categories of humans and animals are not distinguished (cf. López-Rodríguez 2016: 75).
} 
As the PEOPLE ARE ANIMALS metaphor is so prevalent across languages, there has been extensive research on the conceptualization of humans as animals. There are diachronic studies analysing the evolution of certain animal metaphors (cf. Cruz Cabanillas/Tejedor Martínez 2002a, 2006; Kiełtyka 2005; Kiełtyka/Kleparski 2005; López-Rodríguez 2007a, 2014; GóreckaSmolińska/Kleparski 2011; Bisschops 2019). Research has also been dedicated to the issue of translating animal metaphors (cf. Ahrens/Say 1999; Bazzi 2014; Duan/Cui/Gao 2014; Dobrotă 2017). Other studies have focused on the behavioural impact that animal metaphors can have (cf. Bock/Burkley 2018; Tipler/Ruscher 2019), investigated the offensiveness of animal metaphors (cf. Haslam/Loughnan/Sun 2011), and studied which animal metaphors tend to be applied to men and which ones to women (cf. Nilsen 1996; Sommer/Sommer 2011). Most of the research on animal metaphor, however, has been contrastive analyses of two or more languages, highlighting the similarities and differences between commonly found animal metaphors (cf. Nesi 1995; Miri/Soori 2015), and cognitive linguistic analyses demonstrating the metaphorical conceptualizations prevalent in animal metaphors (cf. Hines 1999a; Hermanson/Plessis 1997; Cruz Cabanillas/Tejedor Martínez 2002b; Echevarría Isusquiza 2003; Goatly 2006; LópezRodríguez 2007b, 2016; Molina Plaza 2008; Eggertsson/Forceville 2009; Silaški 2013; Sanz Martin 2015; Kobia 2016). Many studies, though, combine the two approaches, resulting in contrastive cognitive linguistic analyses (cf. Fernández Fontecha/Jiménez Catalán 2003; Hsieh 2004, 2006, 2009; Reza Talebinejad/Vahid Dastjerdi 2005; Kiełtyka/Kleparski 2007; Wang/Dowker 2008; López-Rodríguez 2009; Wei 2011; Wei/Wong 2012; Jiang/Wen 2014; Kilyeni/Silaški 2014; Waśniewska/Kudin 2018).

As Kiełtyka/Kleparski (2007) point out - referring to research conducted by Thornton (1988) -, in English animal metaphors, humans are conceptualized as mammals far more often than as any other animal category. Table 1 shows the ranking of animal categories (source domain) used in the conceptualization of humans (target domain).

\begin{tabular}{|l|l|}
\hline Rank & Animal category used in the conceptualization of humans \\
\hline 1 & mammals \\
\hline 2 & insects, reptiles, birds \\
\hline 3 & fish \\
\hline 4 & arachnids, amphibians \\
\hline 5 & crustaceans \\
\hline
\end{tabular}

Table 1: Frequency ranking of animal categories used in the conceptualization of humans (cf. Kieltyka/Kleparski 2007: 89)

The preference for mammals as source concepts is "due to their widely-understood similarity, familiarity and closeness to mankind" (Kiełtyka/Kleparski 2007: 89). Additionally, as suggested by Hines (1999a: 15), common animals, such as monkey, rat and sheep, appear more often in animal metaphor than rarer animals, such as polar bear, porcupine and zebra (cf. also Sanz Martin 2015: 380).

In line with the finding that men tend to rank above women on the Great Chain of Being (see above), it has been shown that women are conceptualized as animals more often than men and in more variety regarding the types of animals (cf. López-Rodríguez 2009). Furthermore, animal metaphors referring to women are overall more derogatory than those referring to men (cf. 
Fernández Martín 2011). This is especially the case for animal metaphors denoting sexual behaviour, such as promiscuity (cf. Fernández Fontecha/Jiménez Catalán 2003). For example, while both lion and lioness refer to a sexually active, dominant man or woman respectively, the former is endowed with positive associations of male courage, ferocity, and strength, whereas the latter equates the woman with a dangerous and voracious animal, implying a threat to man's hegemonic masculinity (cf. Crespo-Fernández 2015: 147f.). López-Rodríguez (2009) explains the gender imbalance when it comes to (English and Spanish) animal metaphors as follows:

Drawing a clear boundary between the rational human and the instinctual beast, animal metaphors are often used in English and Spanish to degrade particular social groups that are regarded as inferior or marginal. Obviously, taking into account that within the English- and Spanish-speaking world, the male white heterosexual is assumed to be the norm, that is, "the self", any other social group deviating from this, such as women ... will fall into the category of "the other". Belittlement of such "other" [...] is often carried out via animal metaphors, as though implying the inappropriateness of their behavior.

(ibd.: 94f.)

López-Rodríguez (2007b) shows that women tend to be conceptualized as animals belonging to three main categories, namely pets (bitch, kitten, cat), farm animals (mare, hen) and wild animals (vixen, crow). While the first two categories tend to carry positive connotations, the latter category is tied to unfavourable associations:

Obviously, from the human perspective, pet and farmyard animals are domesticated and tamed, depend on man for their survival and do not pose any threat. Wild animals, by contrast, are not subject to man's control and are menacing. Hence, by portraying women in the guise of pets and farm animals, the idea of domesticity is being highlighted, evoking the patriarchal view that a woman's place should be confined to the domestic arena. Leaving their designated domestic sphere, however, is linguistically castigated by endowing the names of wild animals with negative associations.

(López-Rodríguez 2009: 95)

In her study on animal metaphors used by the written media to speak about women and their relationship with food, López-Rodríguez (2016) points out that an animal's size also plays a crucial role regarding the associations portrayed by the conceptualization. Hence, as suggested by Hines (1999a: 9, 17), the metaphor DESIRED WOMAN IS A SMALL ANIMAL likens young and attractive women to small animals, such as bird, mink and bunny. Furthermore, Hines (1999a: 12) argues that in most cases small animals are only mapped if they remain small in size when mature (e. g. cat, chicken), otherwise the immature animal is used (e. g. filly instead of mare). Sometimes though, both the immature and mature animal coexist, which can be seen in the pairs kitten/cat and chick/chicken. When it comes to larger animals, they tend to be perceived as menacing and negative (e. g. mare, nag, seal, walrus or coyote). Thus, when applied to women, these animal metaphors are offensive and pejorative (cf. López-Rodríguez 2016: 95). This goes hand in hand with perceived weakness and strength of certain animals so that referring to women as weak animals (e. g. chicken, Sp. pollita 'chick') appears to have positive connotations, whereas when it comes to strong animals (e. g. vixen, Sp. zorra 'vixen') the associations are negative (cf. López-Rodríguez 2009: 95). 
In her study of metaphorical lexicalization, Hines (1999a) makes the interesting discovery that the animals in her list of active central terms denoting women considered sexually - bird, bunny, canary, cat, chick, filly, fox, goose, grouse, kitten, partridge, pigeon, plover, pussy (cat) and quail - seem to not only be chosen based on their semantic properties but also their phonetic features. Thus, "[e]very central term begins with a labial or velar obstruent" (ibd.: 11). ${ }^{2}$ Hines (1999a: 11) argues that this sound symbolism is explicable as labials and velars have been shown to be associated with derogation in English. However, while animal terms like coyote and flamingo match the phonetic, but not the semantic prototype, hamster and stork fit semantically, but not phonetically (cf. ibd.: 14). This interplay of phonetics and semantics is not unique to this specific metaphor but instead also exists in the metaphors WOMAN IS A DESSERT, manifested, for example, in cookie and cupcake denoting an attractive woman (cf. Hines 1999b), and WOMAN IS A FEMME FATALE, manifested, for example, in harpy to refer to a grasping, unpleasant woman (cf. Hines 1996).

In her analysis of English and Spanish animal metaphors, López-Rodríguez (2009) shows that the two languages share many patterns and similarities when it comes to the conceptualization of women as animals. In both languages, men tend to predominantly be conceptualized as big, strong, and wild animals (e. g. wolf, Sp. toro 'bull'), while women are mainly referred to as a variety of pets and farmyard animals or as wild animals. For example, both dog and Sp. perro are used to denote an ugly woman. Parakeet and the Spanish equivalent periquita both refer to a young woman, and rabbit and its Spanish counterpart coneja denote a woman with many children. However, there are also clear differences between the two languages: Bird, for example, is used affectionately in English to denote a girl or young woman, whereas Sp. pájara refers to a cunning woman or prostitute. Furthermore, vixen is applied to an ill-tempered quarrelsome woman, while Sp. zorra denotes a cunning or promiscuous woman or a prostitute (cf. LópezRodríguez 2009: 83, 86, 88, 91f.). Striking differences as well as interesting similarities were also found by Fernández Fontecha/Jiménez Catalán (2003) in their contrastive-cognitive analysis of two male/female examples in English and Spanish. Investigating the animal pairs fox/vixen and bull/cow as well as their Spanish counterparts zorro/zorra and toro/vaca, the authors found semantic derogation in both languages and more so for women compared to men, which seems to be evidence for the hypothesis of semantic imbalance in language (cf. ibd.: 792). Regarding the derogation conveyed by the female animal terms, there are clear differences between the two languages:

[W]ith regard to the animal pairfox/vixen-zorro/zorra, Spanish is more derogatory to women than English in view of the fact that in Spanish, women are related to promiscuous sexual behavior, whereas this is not so in English. On the other hand, regarding the animal pair bull/cow-toro/vaca, English proves to be more derogatory since, among other things, in the main metaphor from cow, women are associated not only with negative physical aspects, i. e. unattractiveness or large size, but also with negative behavioral aspects such as coarseness.

(ibd.: 793)

\footnotetext{
2 The only exception is chick which is "unsurprising [...] [as] the palato-alveolar affricate/č/ is a common element in diminutives and pet names" (Hines 1999a: 11).
} 
Thus, Fernández Fontecha/Jiménez Catalán (2003: 789) argue that, when it comes to attempting to measure derogation, a negative behavioural aspect weighs heavier than a negative physical aspect and among negative behavioural aspects female promiscuity is considered the worst.

The many above-mentioned findings from previous research on animal metaphors are of utmost importance for the analysis of the results of the present study whose methodology is introduced in the next section, followed by the presentation and discussion of the results.

\section{$3 \quad$ Methodology}

In order to detect native speakers' associations with documented and undocumented Spanish animal metaphors, two online questionnaires were created using the web application SoSci Survey. Participants only took part in one of the two questionnaires by means of randomization. In both questionnaires, the participants were shown 15 Spanish sentences of the type Ana es una musaraña 'Ana is a shrew', with one sentence per page and only the animal term changing on each page. In order to test Spanish speakers' associations with undocumented animal metaphors and to compare them to their English meanings, ten animal metaphors referring to certain types of women which are documented in English but not in Spanish were translated into Spanish (see Table 2, white cells). Additionally, three well-documented Spanish animal metaphors referring to certain types of women were included in the questionnaire (see Table 2, light grey cells) as well as two animal metaphors that are undocumented in both languages (see Table 2, dark grey cells). This design was chosen in order to be able to draw conclusions about animal metaphor interpretation depending on the degree of metaphor conventionality. Table 2 shows the 15 Spanish animal terms that were included in the questionnaire as well as their English equivalents:

\begin{tabular}{|c|c|c|c|}
\hline \multicolumn{2}{|l|}{ English } & \multicolumn{2}{|l|}{ Spanish } \\
\hline $\begin{array}{l}\text { animal } \\
\text { term }\end{array}$ & meaning & translation & $\begin{array}{l}\text { metaphor } \\
\text { conventionality }\end{array}$ \\
\hline quail & young woman & codorniz & $\begin{array}{l}\text { novel metaphor that fol- } \\
\text { lows mapping principle }\end{array}$ \\
\hline shrew & $\begin{array}{l}\text { ill-tempered; malignant; aggressive; } \\
\text { quarrelsome woman }\end{array}$ & musaraña & $\begin{array}{l}\text { novel metaphor that fol- } \\
\text { lows mapping principle }\end{array}$ \\
\hline roach & $\begin{array}{l}\text { unpleasant; despicable; unattractive; } \\
\text { licentious woman }\end{array}$ & cucaracha & $\begin{array}{l}\text { novel metaphor that fol- } \\
\text { lows mapping principle }\end{array}$ \\
\hline mouse & young woman & ratón & $\begin{array}{l}\text { novel metaphor that fol- } \\
\text { lows mapping principle }\end{array}$ \\
\hline beaver & sexually attractive woman & castor & $\begin{array}{l}\text { novel metaphor that fol- } \\
\text { lows mapping principle }\end{array}$ \\
\hline stud & $\begin{array}{l}\text { homosexual woman with a stereo- } \\
\text { typically masculine identity or ap- } \\
\text { pearance }\end{array}$ & semental & $\begin{array}{l}\text { novel metaphor that fol- } \\
\text { lows mapping principle }\end{array}$ \\
\hline trout & $\begin{array}{l}\text { unattractive; old; ill-tempered } \\
\text { woman }\end{array}$ & trucha & $\begin{array}{l}\text { novel metaphor that fol- } \\
\text { lows mapping principle }\end{array}$ \\
\hline
\end{tabular}




\begin{tabular}{|c|c|c|c|}
\hline \multicolumn{2}{|l|}{ English } & \multicolumn{2}{|l|}{ Spanish } \\
\hline $\begin{array}{l}\text { animal } \\
\text { term }\end{array}$ & meaning & translation & $\begin{array}{l}\text { metaphor } \\
\text { conventionality }\end{array}$ \\
\hline bat & $\begin{array}{l}\text { unattractive; promiscuous; disagree- } \\
\text { able; foolish woman; or a prostitute } \\
\text { who walks the streets at night }\end{array}$ & murciélago & $\begin{array}{l}\text { novel metaphor that fol- } \\
\text { lows mapping principle }\end{array}$ \\
\hline crow & unattractive; old woman & cuervo & $\begin{array}{l}\text { novel metaphor that fol- } \\
\text { lows mapping principle }\end{array}$ \\
\hline partridge & attractive woman & perdiz & $\begin{array}{l}\text { novel metaphor that fol- } \\
\text { lows mapping principle }\end{array}$ \\
\hline vixen & promiscuous; cunning woman & zorra & conventional metaphor \\
\hline cow & fat; unattractive woman & vaca & conventional metaphor \\
\hline lizard & promiscuous; cunning woman & lagarta & conventional metaphor \\
\hline stork & - & cigüeña & $\begin{array}{l}\text { novel metaphor that fol- } \\
\text { lows mapping principle }\end{array}$ \\
\hline otter & - & nutria & $\begin{array}{l}\text { novel metaphor that fol- } \\
\text { lows mapping principle }\end{array}$ \\
\hline
\end{tabular}

Table 2: The 15 animal terms included in the questionnaire ${ }^{3}$

Some of the animal terms of the study have masculine gender (ratón, castor, semental, murciélago, cuervo), some feminine gender (codorniz, musaraña, cucaracha, trucha, perdiz, zorra, vaca, lagarta, cigüeña, nutria). To determine which animal terms would sound unknown or unacceptable to the participants, three native speakers judged all animal terms for which both masculine and feminine forms exist (e. g. castor vs. castora, ratón vs. ratona) in advance and unanimously decided on the above arrangement.

The ten animal metaphors that are documented to exist in English but not in Spanish were chosen based on an English dictionary search of the following dictionaries:

- $\quad$ The Oxford English Dictionary (OED), online version

- The New Partridge Dictionary of Slang and Unconventional English (Partridge 2013)

- The Oxford Dictionary of Modern Slang (Ayto/Simpson 2013)

The English animal terms were then directly translated into Spanish and - in order to determine if the Spanish animal terms were documented to exist as metaphors for certain types of women - they were subsequently cross-checked with a Spanish dictionary search of the following dictionaries:

- Diccionario de la lengua española de la Real Academia Española (DRAE), online version

- Diccionario de uso del español, CD-ROM version (Moliner 2008)

- Diccionario del sexo y el erotismo (Rodríguez González 2011)

\footnotetext{
${ }^{3}$ Animal terms in white cells represent animal metaphors that are documented to exist in English but not in Spanish, animal terms in light grey cells represent well-documented Spanish animal metaphors, animal terms in dark grey cells represent animal metaphors that neither exist in English nor Spanish.
} 
Additionally, the process was supported by a Google search in both languages. By including not only animal terms that are documented in English and undocumented in Spanish (a), but also well-documented animal terms in Spanish (b) as well as animal terms that are undocumented in both languages (c), it is possible to put the results obtained from (a) in relation to likely highly accepted animal terms (b) as well as likely highly unaccepted animal terms (c). However, as indicated in Table 2, it is important to keep in mind that the metaphorical animal terms in (b) could be classified as conventional metaphors, while those in (a) and (c) could be classified as novel metaphors that follow mapping principles as animal metaphors of the respective classes of animals do exist in Spanish.

In terms of categorizing the animals featured in this study, two approaches can be helpful. Firstly, the animals belong to the following animal classes: mammals (musaraña 'shrew', ratón 'mouse', castor 'beaver', semental 'stud', murciélago 'bat', zorra 'vixen', vaca 'cow', nutria 'otter'), insects (cucaracha 'roach'), reptiles (lagarta 'lizard'), birds (codorniz 'quail', cuervo 'crow', perdiz 'partridge', cigüeña 'stork'), and fish (trucha 'trout'). Secondly, following López-Rodríguez' (2007b: 26-32) classification, the animals in this study are either farm animals/typically edible animals (codorniz 'quail', semental 'stud', vaca 'cow', trucha 'trout', perdiz 'partridge') or wild animals/typically inedible animals (musaraña 'shrew', cucaracha 'roach', ratón 'mouse', castor 'beaver', murciélago 'bat', cuervo 'crow', zorra 'vixen', lagarta 'lizard', cigüeña 'stork', nutria 'otter').

In the first questionnaire, the participants were asked to rate each animal term on a separate page on ten individual 7-point Likert scales from 0 to 6 . The value 0 corresponded to no significa lo mismo en absoluto, no sería posible usar esta expresión en este sentido 'does not mean the same at all, it would not be possible to use this expression in this sense', the value 6 corresponded to totalmente significa lo mismo, sería posible usar esta expresión en este sentido 'totally means the same, it would be possible to use this expression in this sense'. The scales remained the same on every page, i. e. for every animal term. For every single scale the participants had the option to indicate no sé 'I don't know'. The following scales were included (in Spanish only):

(a) Ana es una mujer gorda. 'Ana is a fat woman.'

(b) Ana es una mujer guapa. 'Ana is a good-looking woman.'

(c) Ana es una mujer promiscua. 'Ana is a promiscuous woman.'

(d) Ana es una mujer sexi. 'Ana is a sexy woman.'

(e) Ana es una mujer amable. 'Ana is a kind woman.'

(f) Ana es una mujer anciana. 'Ana is an old woman.'

(g) Ana es una mujer cizañera. 'Ana is a quarrelsome woman.'

(h) Ana es una mujer lesbiana. 'Ana is a lesbian woman.'

(i) Ana es una mujer joven. 'Ana is a young woman.'

(j) Ana es una mujer fea. 'Ana is an ugly woman.'

Figure 1 shows a screenshot of the questionnaire page for the animal term zorra 'vixen'. All pages were identical with only the animal term changing per page.

In the second questionnaire, for every animal term the participants were asked the same type of open question, for example, ¿Cómo describirías el tipo de mujer que es una musaraña? 'How 
would you describe a woman who is a shrew?', which they answered in an empty text box. For each animal term, the participants could instead indicate no sé 'I don't know' (see Figure 2).

All participants were Spanish native speakers from Spain. They were aged between 22 years and 72 years, with a mean age of 36.15 years. Overall, 112 participants took part in the study, with 59 in the first questionnaire (Likert scales) and 53 in the second (open questions). Among the participants of the first questionnaire were 34 women, 24 men, and one intersexual participant. Among the participants of the second questionnaire were 37 women, 15 men, and one participant who indicated otro 'other' when asked about their gender. Additionally, the participants were asked to indicate their level of English on a 5-point Likert scale, with 1 corresponding to very bad English skills and 5 corresponding to very good English skills. The mean value of the participants' English skills was 3.92 in the first questionnaire and 4.15 in the second questionnaire. The participation in the study was voluntary and the participants did not receive any compensation. The study was conducted in September and October of 2020.

\section{Ana es una zorra.}

Indique el grado en que la frase arriba significa lo mismo que cada de las frases abajo.

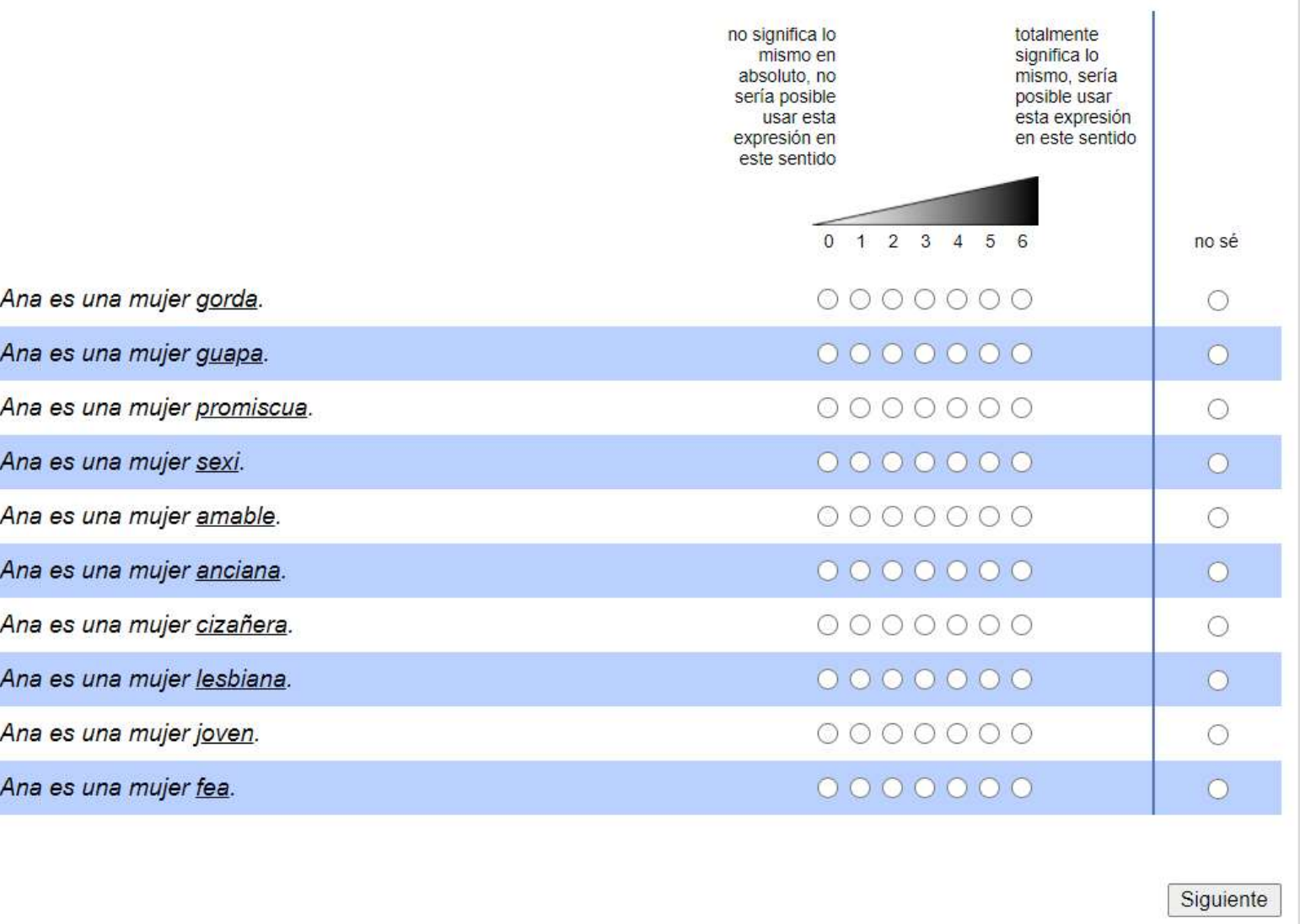

Figure 1: Screenshot of the questionnaire page for the animal term zorra 'vixen' as presented to the participants of the first questionnaire (Likert scales) 


\section{Ana es una zorra.}

¿Cómo describirias el tipo de mujer que es una zorra?

$\square$ no sé

Figure 2: Screenshot of the questionnaire page for the animal term zorra 'vixen' as presented to the participants of the second questionnaire (open questions)

\section{$4 \quad$ Results}

In this section, the results of the study are presented. Firstly, the results obtained from the first questionnaire (Likert scales) are shown and analysed, followed by the results obtained from the second questionnaire (open questions). This allows for both theoretical and methodological conclusions. It is important to note that no significant differences were found between the overall results of the participants of either questionnaire regarding the social variables (gender, age, English skills). However, in some cases, the participants' English skills do provide additional meaningful information.

\subsection{Questionnaire I: Likert scales}

Table 3 shows the 20 animal terms with the highest mean values for a single character trait. Put differently, vaca 'cow' is the animal term which was rated the highest out of all the animal terms as referring to a fat woman more than any other one of the remaining nine character traits. As can be seen, with a mean rating of 5.71 it is closest to the high end of 6 , which corresponds to 'totally means the same, it would be possible to use this expression in this sense'.

\begin{tabular}{|l|l|l|l|}
\hline Rank & Animal term & Character trait & Mean value (between 0 and 6) \\
\hline 1 & vaca 'cow' & fat & 5.71 \\
\hline 2 & zorra 'vixen' & promiscuous & 4.63 \\
\hline 3 & lagarta 'lizard' & promiscuous & 3.24 \\
\hline 4 & lagarta 'lizard' & quarrelsome & 3.22 \\
\hline 5 & zorra 'vixen' & quarrelsome & 3.07 \\
\hline 6 & semental 'stud' & promiscuous & 2.54 \\
\hline 7 & cucaracha 'roach' & ugly & 2.44 \\
\hline 8 & cucaracha 'roach' & quarrelsome & 2.34 \\
\hline 9 & trucha 'trout' & lesbian & 2.26 \\
\hline 10 & cuervo 'crow' & ugly & 2.11 \\
\hline 11 & semental 'stud' & sexy & 1.81 \\
\hline 12 & castor 'beaver' & ugly & 1.69 \\
\hline 13 & murciélago 'bat' & ugly & 1.66 \\
\hline 14 & vaca 'cow' & ugly & 1.59 \\
\hline
\end{tabular}




\begin{tabular}{|l|l|l|l|}
\hline Rank & Animal term & Character trait & Mean value (between 0 and 6) \\
\hline 15 & ratón' 'mouse' & ugly & 1.45 \\
\hline 16 & cuervo 'crow' & quarrelsome & 1.45 \\
\hline 17 & trucha 'trout' & ugly & 1.36 \\
\hline 18 & zorra 'vixen' & sexy & 1.25 \\
\hline 19 & musaraña'shrew' & ugly & 1.20 \\
\hline 20 & lagarta 'lizard' & sexy & 1.12 \\
\hline
\end{tabular}

Table 3: The 20 animal terms with the highest mean value for a single character trait ${ }^{4}$

Unsurprisingly, the three well-documented Spanish animal terms (zorra 'vixen', vaca 'cow', lagarta 'lizard'; see 3) appear in the five highest ranks. Additionally, the two animal metaphors that neither exist in English nor Spanish (cigüeña 'stork', nutria 'otter') do not feature at all in the 20 highest entries. When looking at the entries in Table 3, it is striking that some character traits seem to clearly feature more than others. Accordingly, while vaca 'cow' to refer to a fat woman is the highest-ranking entry, the character trait fat does not appear apart from that. Instead, the single most frequently character trait appears to be ugly $(8 / 20)$, followed by quarrelsome (4/20), promiscuous, and sexy (both 3/20). Another character trait with only one instance among the 20 highest entries is lesbian. Thus, the character traits good-looking, kind, old, and young do not feature at all in the 20 highest entries. This tendency also reveals itself when considering the mean values of all ten character traits for all 15 animal terms per character trait, as shown in Table 4.

\begin{tabular}{|l|l|l|}
\hline Rank & Character trait & Mean value (between 0 and 6), considering all animal terms \\
\hline 1 & ugly & 1.14 \\
\hline 2 & promiscuous & 0.91 \\
\hline 3 & quarrelsome & 0.89 \\
\hline 4 & fat & 0.68 \\
\hline 5 & sexy & 0.52 \\
\hline 6 & lesbian & 0.40 \\
\hline 7 & good-looking & 0.35 \\
\hline 8 & young & 0.33 \\
\hline 9 & old & 0.33 \\
\hline 10 & kind & 0.30 \\
\hline
\end{tabular}

Table 4: Mean values of all ten character traits, considering all 15 animal terms per character trait $^{5}$

As mentioned above, good-looking, young, old, and kind score the lowest mean values, indicating that the participants perceive the animal terms tested in this study to overall not refer to women who inherit these character traits. Instead, they perceive them to mostly refer to ugly,

\footnotetext{
${ }^{4}$ A mean value of 6 corresponds to 'totally means the same, it would be possible to use this expression in this sense', a mean value of 0 corresponds to the opposite. Animal terms in light grey cells represent well-documented Spanish animal metaphors, animal terms in white cells represent animal metaphors that are documented to exist in English but not in Spanish.

${ }^{5}$ A mean value of 6 corresponds to "totally means the same, it would be possible to use this expression in this sense", a mean value of 0 corresponds to the opposite.
} 
promiscuous, and quarrelsome women, followed by fat, sexy, and lesbian women. However, the overall mean values are relatively small, i. e. rather than approaching the high end of 6 , they approach the low end of 0 which corresponds to "does not mean the same at all, it would not be possible to use this expression in this sense".

Apart from the most common character traits, Table 3 also gives an indication of the animal terms that are most highly rated as referring to a woman of a specific character trait. As mentioned above, the three well-documented Spanish animal terms (zorra 'vixen', vaca 'cow', lagarta 'lizard') appear in the highest ranks. This tendency remains the same when looking at the mean value of all the animal term data obtained from this questionnaire. Table 5 shows the mean values of all 15 animal terms for all ten character traits per animal term.

\begin{tabular}{|l|l|l|}
\hline Rank & Animal term & Mean value (between 0 and 6), all character traits \\
\hline 1 & zorra 'vixen' & 1.17 \\
\hline 2 & lagarta 'lizard' & 0.98 \\
\hline 3 & vaca 'cow' & 0.97 \\
\hline 4 & semental 'stud' & 0.76 \\
\hline 5 & cucaracha 'roach' & 0.67 \\
\hline 6 & cuervo 'crow' & 0.58 \\
\hline 7 & trucha 'trout' & 0.54 \\
\hline 8 & codorniz'quail' & 0.46 \\
\hline 9 & nutria 'otter' & 0.42 \\
\hline 10 & ratón 'mouse' & 0.41 \\
\hline 11 & murciélago 'bat' & 0.41 \\
\hline 12 & musaraña 'shrew' & 0.41 \\
\hline 13 & perdiz 'partridge' & 0.35 \\
\hline 14 & castor 'beaver' & 0.35 \\
\hline 15 & cigüeña 'stork' & 0.30 \\
\hline
\end{tabular}

Table 5: Mean values of all 15 animal terms, considering all ten character traits per animal term 6

In other words, the participants perceive zorra 'vixen', lagarta 'lizard', and vaca 'cow' to be the three animal terms that most likely refer to certain types of women overall, while cigüeña 'stork', castor 'beaver', and perdiz 'partridge' are considered the least likely animal terms to refer to certain types of women. Other relatively highly rated animal terms include semental 'stud', cucaracha 'roach', cuervo 'crow', and trucha 'trout' - all animal terms that are documented to refer to certain types of women in English but not in Spanish (see 3).

It is worth looking at each animal term and its respective character traits in more detail. Figure 3 shows the participants' ratings of every animal term based on all ten character traits. It aligns with the data in Table 3. As can be seen, while some animal terms, e. g. zorra 'vixen', vaca

\footnotetext{
${ }^{6}$ A mean value of 6 corresponds to "totally means the same, it would be possible to use this expression in this sense", a mean value of 0 corresponds to the opposite. Animal terms in light grey cells represent well-documented Spanish animal metaphors, animal terms in white cells represent animal metaphors that are documented to exist in English but not in Spanish, animal terms in dark grey cells represent animal metaphors that neither exist in English nor Spanish.
} 
'cow', lagarta 'lizard', cucaracha 'roach', and semental 'stud', have high mean values for certain character traits, not a single character trait of the bird terms codorniz 'quail', perdiz 'partridge', and cigüeña 'stork' scores a mean value of 1 or higher. While none of the three birds seem to make for potential source concepts, there are interesting differences between them, after all: Based on the ten character traits, the participants rate codorniz 'quail' to most likely refer to an ugly (0.67), but also sexy (0.57) and good-looking woman (0.56), and least likely to a fat (0.30) and lesbian woman (0.30); perdiz 'partridge' to most likely refer to a young $(0.60)$ and kind woman (0.58), and least likely to a lesbian (0.22), quarrelsome (0.22), and old woman (0.22); and cigüeña 'stork' to most likely refer to an ugly (0.59) and interestingly also a goodlooking woman (0.54), and least likely to a quarrelsome (0.12) and lesbian woman (0.13). In English, only quail and partridge are documented out of those three bird metaphors, with the former referring to a young woman and the latter to an attractive woman. Thus, the associations evoked by the English conventional metaphors and the Spanish translations differ in these cases.

Apart from the three well-documented animal metaphors zorra 'vixen', vaca 'cow', and lagarta 'lizard', the animal terms which score a mean value of 2 or more for at least one character trait are semental 'stud', cucaracha 'roach', trucha 'trout', and cuervo 'crow' (see Table 3 and Figure 3) - all documented to exist in English but not in Spanish. In comparison with the associations in English, the Spanish associations reveal interesting results: Both cucaracha 'roach' and cuervo 'crow' seem to align to a great extent with their English counterparts when it comes to the perceived character traits. The former refers to an unpleasant, despicable, ugly, and licentious woman in English, and is rated as referring to a quarrelsome and ugly woman in Spanish. The latter refers to an old and ugly woman in English, and is considered to refer to an ugly, quarrelsome, and old woman by the Spanish participants.

When it comes to semental 'stud' and trucha 'trout', however, the Spanish participants' associations seem to differ from those documented in English. While stud refers to a homosexual woman of stereotypically masculine identity or appearance in English, the Spanish participants perceive semental 'stud' to predominantly refer to a promiscuous and sexy woman. However, the character trait with the third highest mean value is in fact lesbian, although it is far behind promiscuous and sexy (see Figure 3). A possible reason for the Spanish participants' focus on sexual activity and attractiveness - instead of homosexuality - might be the association of a stud with frequent mating and high sex hormone levels. This topic is discussed in more detail in 5. Regarding trucha 'trout', the animal term is used in English to refer to an ugly, old, and ill-tempered woman. However, while the character trait $u g l y$ does have the second highest mean value, it is lesbian that scores the highest mean value by far (see Figure 3). This high rating likely occurs due to the fact that trucha 'trout' is a documented expression for a homosexual man - but not for a homosexual woman. It seems, then, that the participants extended this association to female homosexuality. This case is discussed in more detail in 5. 


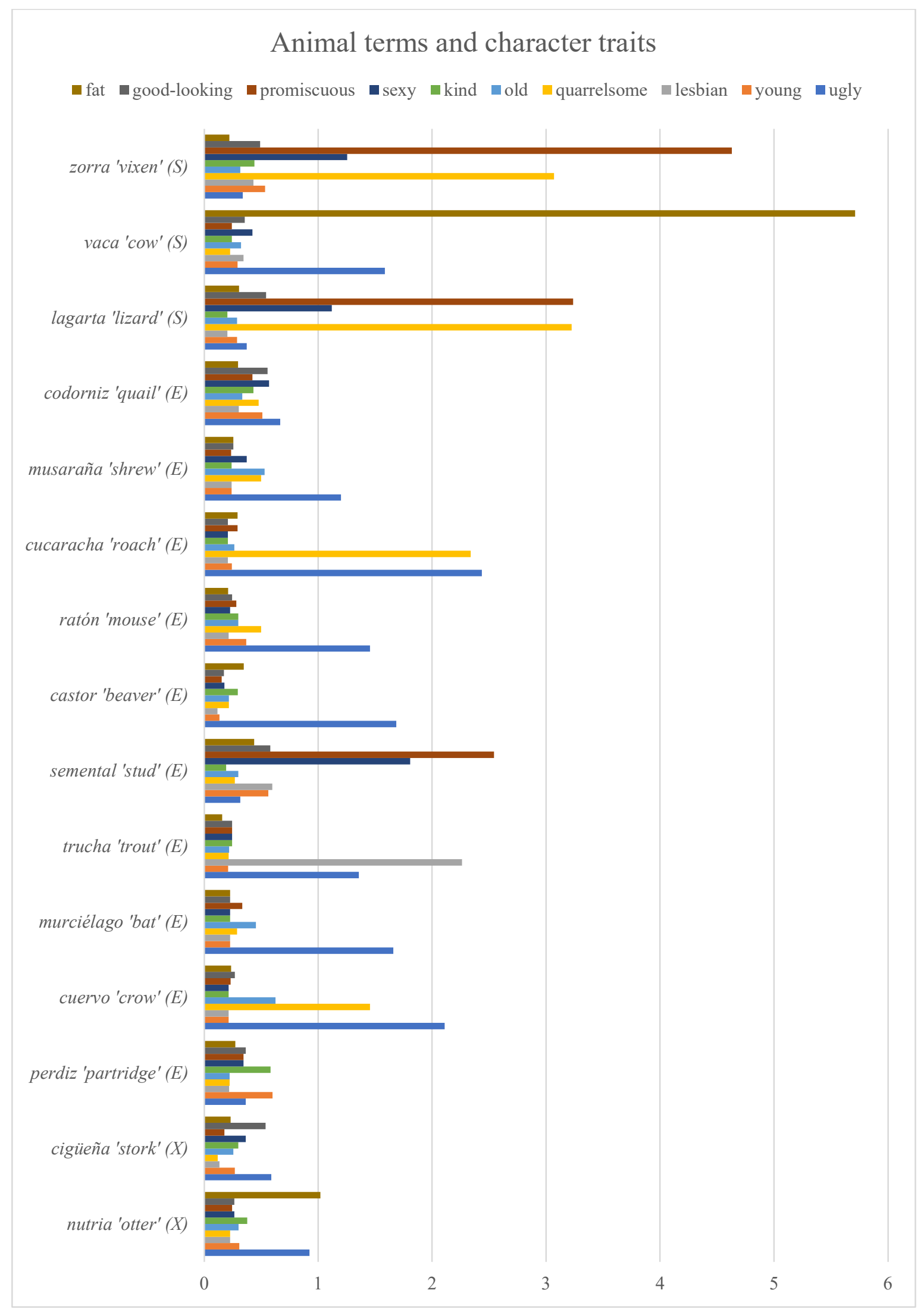

Figure 3: All animal terms and the respective character traits 7

${ }^{7}$ The letters in brackets indicate whether an animal metaphor is well-documented in Spanish (S), documented to exist in English but not Spanish (E), or not documented in either language (X). 
Some additional interesting findings include the following: Apart from the character trait promiscuous, both zorra 'vixen' and lagarta 'lizard' - two well-documented animal metaphors in Spanish - also have high ratings for the character trait quarrelsome (see Figure 3). In fact, in the case of lagarta 'lizard', the scores of the character traits promiscuous (3.24) and quarrelsome (3.22) are nearly identical. Interestingly, the English vixen is documented to refer to an ill-tempered, quarrelsome woman. However, for both zorra 'vixen' and lagarta 'lizard', this part of the meaning seems to be novel and, so far, undocumented, as the following dictionary entries highlight:

- zorra ‘vixen' (cf. Rodríguez González 2011: 1089)

Referido a la mujer fácil, promiscua, muy laxa en lo tocante a la moral sexual; prostituta. 'Referring to an easy, promiscuous woman, very lax regarding sexual morality; prostitute.'

- lagarta 'lizard' (cf. DRAE, s. v. lagarta)

Persona picara, taimada; prostituta. 'Naughty, cunning person; prostitute.'

A Google search for zorra 'vixen' and lagarta 'lizard' in combination with cizañera 'quarrelsome' did not yield fruitful results either, suggesting that this character trait is in fact undocumented as part of the meaning of the two animal metaphors.

Furthermore, Figure 3 also nicely visualizes that the character trait ugly has the overall highest mean value (see Table 4). Out of the 15 animal terms, it scores the highest mean value in eight of them (codorniz 'quail', musaraña 'shrew', cucaracha 'roach', ratón 'mouse', castor 'beaver', murciélago 'bat', cuervo 'crow', cigüeña 'stork'). For three additional animal terms, ugly has the second highest score (vaca 'cow', trucha 'trout', nutria 'otter'). The question arises whether this tendency is due to the specific animals featuring in this study or whether this might be a more general tendency in Spanish animal metaphors. This is further discussed in 5.

Apart from vaca 'cow', the only other highly rated animal term regarding the character trait fat is nutria 'otter' - an undocumented animal metaphor in both English and Spanish. For both animal terms, fat has the highest and ugly the second highest rating, implying that being corpulent is regarded an unattractive and therefore negative feature. This has been previously shown to be the case for vaca 'cow' (cf. López-Rodríguez 2009: 88).

While it is, of course, important to consider in detail the ratings that each animal term received regarding the character traits, the instances of participants indicating that they did not know which character traits to assign to an animal, i. e. where they chose no sé 'I don't know', offer some interesting insights too. Thus, while the three well-documented Spanish animal metaphors zorra 'vixen', vaca 'cow', and lagarta 'lizard' each unsurprisingly received only one indication of no sé 'I don't know' (each one for the character trait quarrelsome), the results for the remaining animal terms suggests significantly more insecurity among the participants (and for all character traits), as Figure 4 shows. 


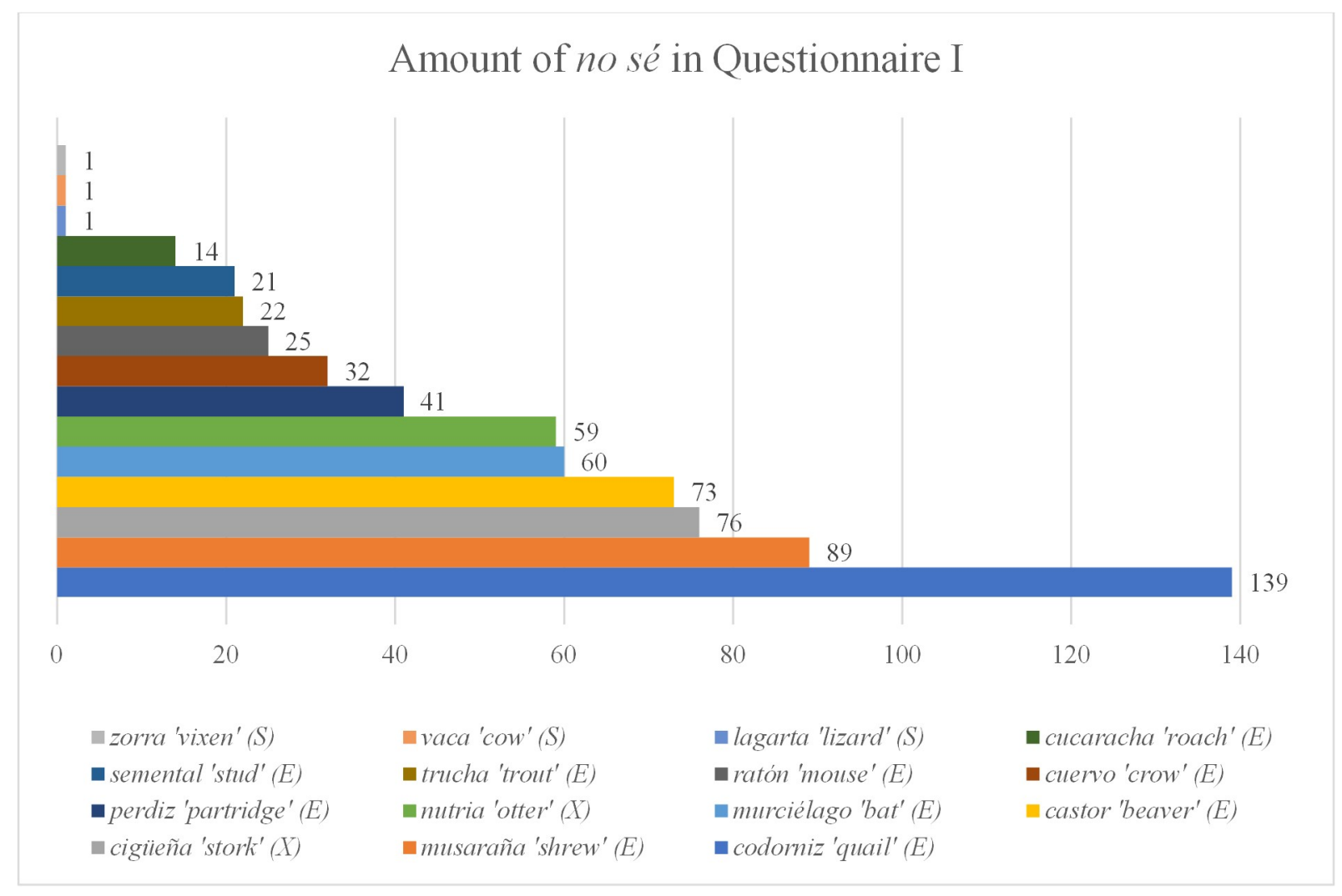

Figure 4: Total amount of no sé 'I don't know' in the Likert scale questionnaire ${ }^{8}$

Out of all 8850 data points in the Likert scale questionnaire, i. e. 59 (participants) x 15 (animals) x 10 (character traits), there are 654 instances of no sé 'I don't know', which equals around $7.39 \%$ of all data points. As can be seen in Figure 4, the participants indicated the most insecurity in the case of codorniz 'quail', with 139 instances of no sé 'I don't know', which means that nearly one quarter (23.56\%) of all data points for this animal term are no sé 'I don't know'. For the Spanish translation musaraña of the highly conventionalized English shrew as a metaphor for a quarrelsome woman, participants indicated the second highest amount of no sé 'I don't know'. In fact, English skills seem to not have been beneficial in this case - quite the contrary: Participants who stated to have good or very good English skills indicated no sé 'I don't know' 1.73 times per musaraña 'shrew', compared to 1.05 times for those with bad English skills. What is striking in Figure 4 is the fact that the two animal metaphors that neither exist in English nor Spanish, nutria 'otter' and cigüeña 'stork', do not have the highest amounts of no sé 'I don't know', with nutria 'otter' even featuring in mid-range. This suggests that otter and stork might be equally suited for source domains in animal metaphor as other animals that are indeed documented to exist in English - or even more so than some of them, e. g. quail and shrew. In Japanese folklore, for example, otters are believed to be tricksters and shapeshifters: "They are said to emerge from the water and take human form, often that of a beautiful woman, in order to bewitch unwary travelers" (Toriyama/Yoda/Alt 2016: 17). It seems, then, that animal metaphors are to some degree arbitrary:

\footnotetext{
${ }^{8}$ The numbers are given as indicated per animal term in the Likert scale questionnaire. The letters in brackets indicate whether an animal metaphor is well-documented in Spanish (S), documented to exist in English but not Spanish (E), or not documented in either language (X).
} 
Certainly the real world provides a starting point for metaphor, but the choice of salient feature, and the significance attached to that feature, varies to such an extent as to appear arbitrary. [...] $[C]$ onventional metaphor is not natural but cultural. Once a perceived similarity between two entities is codified, that similarity may even cease to exist, yet the metaphor will remain meaningful.

(Nesi 1995: 276)

Apart from the three well-documented Spanish animal terms zorra 'vixen', vaca 'cow', and lagarta 'lizard' (no sé: $0.17 \%$ ), the participants were most sure about cucaracha 'roach' (no sé: $2.37 \%$ ), followed by semental 'stud' (no sé: 3.56\%), trucha 'trout' (no sé: 3.73\%), and ratón 'mouse' (no sé: $4.24 \%$ ). Interestingly, when it comes to the insecurity about the animal terms featured in this study, it appears not to matter which animal class the animal belongs to, whether the animal is a farm animal/edible animal or a wild animal/inedible animal, and whether or not the animal metaphor is documented in English.

After having highlighted the most noteworthy results obtained from the Likert scales of the first questionnaire, it is time to explore the findings from the second questionnaire employing open questions instead.

\subsection{Questionnaire II: Open questions}

Starting, in this section, with the participants' indication of no sé 'I don't know' per animal term, it becomes clear that the results overlap with those of the first questionnaire to a large extent, though not in all cases, as can be seen in Figure 5, in which the ascending order of Figure 4 has been kept. It is important to note that the overall numbers are smaller in this case as the participants in the second questionnaire could only indicate no sé 'I don't know' once per animal term (instead of answering the question in the empty text box).

Again, unsurprisingly, the participants are least unsure about the well-documented Spanish animal metaphors zorra 'vixen' (no sé: 0), vaca 'cow' (no sé: 0), and lagarta 'lizard' (no sé: 2). This is followed by cucaracha 'roach' (no sé: 8) and semental 'stud' (no sé: 17), just like in the first questionnaire. However, the next animal term is not trucha 'trout' (no sé: 27), but cuervo 'crow' (no sé: 18) and then ratón 'mouse' (no sé: 19). A possible explanation could be that in the first questionnaire the participants were presented with the ten character traits, including lesbian which they indicated to be most prominent. Without any leads as to what type of woman could be referred to as trucha 'trout', it appears more participants were unsure about the animal term. This is discussed in more detail in 5.

Furthermore, while codorniz 'quail' (no sé: 38 ) remains the animal term that the participants are most unsure about, it is not as far behind as in the first questionnaire (see Figure 4), with nutria 'otter' (no sé: 37) and perdiz 'partridge' (no sé: 36) yielding similar results. However, overall, the second questionnaire, employing open questions instead of Likert scales, seems to reveal significantly higher insecurities among the participants, as the percentages indicated in brackets in Figure 5 show. Accordingly, $71.70 \%$ of participants did not know what type of woman codorniz 'quail' could refer to. The only animal terms for which more than half of the 


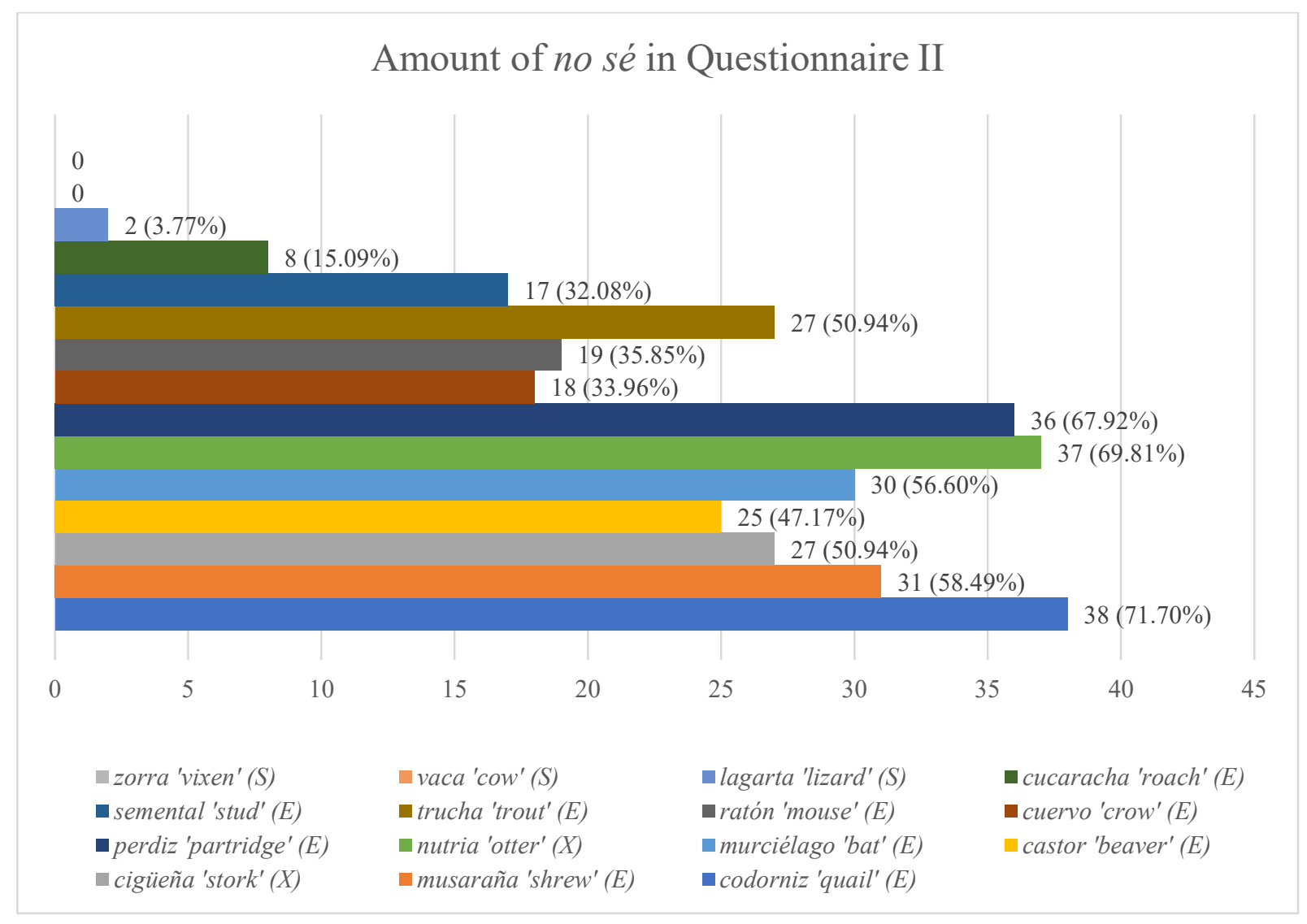

Figure 5: Total amount of no sé 'I don't know'9

participants offered an association with a certain type of woman are the three well-documented Spanish metaphors zorra 'vixen', vaca 'cow', and lagarta 'lizard', as well as the following animal metaphors that are documented in English but not in Spanish: cucaracha 'roach', semental 'stud', cuervo 'crow', ratón 'mouse', and castor 'beaver'. Methodological implications are further discussed in 5 .

Table 6 shows the character traits which the participants indicated for each animal term when used to refer to a woman metaphorically. Only character traits that were mentioned by at least two participants are listed. The last column shows the total amount of all occurrences of character traits that were mentioned at least twice.

\footnotetext{
${ }^{9}$ The answers are indicated per animal term in the open question questionnaire, with the percentage of participants indicating no sé 'I don't know' per animal term in brackets. The letters in brackets indicate whether an animal metaphor is well-documented in Spanish (S), documented to exist in English but not Spanish (E), or not documented in either language $(\mathrm{X})$.
} 


\begin{tabular}{|c|c|c|}
\hline Animal term & Character traits & Total \\
\hline zorra 'vixen' & $\begin{array}{l}\text { promiscuous (31); bad (19); cunning (6); malicious (5); selfish } \\
\text { (4); intelligent (4); perverse (2); hurtful (2); lewd (2); unscrupu- } \\
\text { lous (2); disrespectful (2) }\end{array}$ & 79 \\
\hline lagarta 'lizard' & $\begin{array}{l}\text { promiscuous (13); bad (12); cunning (6); selfish (6); exploitative } \\
\text { (5); mysterious (4); unreliable (4); careerist (2); talks behind peo- } \\
\text { ple's back (2); false (2); interested in unavailable men (2); mali- } \\
\text { cious (2); deceitful (2) }\end{array}$ & 62 \\
\hline vaca'cow' & fat (51); gluttonous (3); lazy (2); large (2) & 58 \\
\hline cucaracha 'roach' & $\begin{array}{l}\text { despicable (16); disgusting (9); bad (7); dirty (7); small (3); dark } \\
\text { (2); insignificant (2) }\end{array}$ & 46 \\
\hline semental 'stud' & $\begin{array}{l}\text { not used to refer to women (8); promiscuous (6); sexual appetite } \\
\text { (5); reproduces a lot (4); sexually potent (3); sexually active ( } 3 \text {;) } \\
\text { transsexual (2); competent (2); coarse (2); attractive (2); mascu- } \\
\text { line (2) }\end{array}$ & 39 \\
\hline cuervo 'crow' & $\begin{array}{l}\text { malicious (6); dark (5); dressed in black (5); intelligent (3); car- } \\
\text { rion-eating (3); big nose (3); afraid of people (2); witch (2); } \\
\text { brings bad luck (2); in low spirits (2); cunning (2); exploitative } \\
\text { (2) }\end{array}$ & 37 \\
\hline ratón 'mouse' & $\begin{array}{l}\text { small (10); likes cheese (4); cunning (4); agile (3); quiet (3); eats } \\
\text { little (2); industrious (2); elusive (2); intelligent (2) }\end{array}$ & 32 \\
\hline castor 'beaver' & big teeth (17); industrious (7); ugly (2); persistent (2) & 28 \\
\hline cigüeña 'stork' & $\begin{array}{l}\text { tall (6); midwife (4); has many children (4); thin (4); cautious } \\
\text { (3); nomadic (2); brings babies (2); long legs (2) }\end{array}$ & 27 \\
\hline trucha 'trout' & $\begin{array}{l}\text { homosexual (10); elusive (5); agile (2); not used to refer to } \\
\text { women (2); stupid (2); industrious (2) }\end{array}$ & 23 \\
\hline murciélago 'bat' & nocturnal (12); likes the night (6); ugly (2) & 20 \\
\hline musaraña'shrew' & scatter-brained (9); quiet (3); small (3); sleepy (2); pensive (2) & 19 \\
\hline codorniz 'quail' & small (7); thin (3); caring (2); familiar (2) & 14 \\
\hline nutria 'otter' & fat (3); quiet (2); likes water (2); industrious (2) & 9 \\
\hline perdiz 'partridge' & happy (6); small (2) & 8 \\
\hline
\end{tabular}

Table 6: Animal terms and their respective character traits 10

As can be seen in Table 6, a number of character traits are mentioned for more than one animal term. Accordingly, small is the most mentioned trait, namely for five animal terms. An overview of all character traits that were mentioned twice or more can be seen in Table 7 .

\footnotetext{
10 The terms are given as indicated by the participants in the open question questionnaire. Only character traits that were mentioned by at least two participants are shown. Animal terms in light grey cells represent well-documented Spanish animal metaphors, animal terms in white cells represent animal metaphors that are documented to exist in English but not in Spanish, animal terms in dark grey cells represent animal metaphors that neither exist in English nor Spanish.
} 


\begin{tabular}{|c|c|c|}
\hline Character trait & Frequency & Animal terms \\
\hline small & $5 x$ & $\begin{array}{l}\text { codorniz 'quail'; musaraña 'shrew'; cucaracha 'roach'; } \\
\text { ratón 'mouse'; perdiz 'partridge' }\end{array}$ \\
\hline cunning & \multirow{2}{*}{$4 \mathrm{x}$} & zorra 'vixen'; lagarta 'lizard'; ratón 'mouse'; cuervo 'crow' \\
\hline industrious & & ratón 'mouse'; castor 'beaver'; trucha 'trout'; nutria 'otter' \\
\hline promiscuous & \multirow{5}{*}{$3 x$} & zorra 'vixen'; lagarta 'lizard'; semental 'stud' \\
\hline bad & & zorra 'vixen'; lagarta 'lizard'; cucaracha 'roach' \\
\hline malicious & & zorra 'vixen'; lagarta 'lizard'; cuervo 'crow' \\
\hline intelligent & & zorra 'vixen'; ratón 'mouse'; cuervo 'crow' \\
\hline quiet & & musaraña 'shrew'; ratón 'mouse'; nutria 'otter' \\
\hline selfish & \multirow{8}{*}{$2 \mathrm{x}$} & zorra 'vixen'; lagarta 'lizard' \\
\hline fat & & vaca 'cow'; nutria 'otter' \\
\hline exploitative & & lagarta 'lizard'; cuervo 'crow' \\
\hline thin & & codorniz 'quail'; cigüeña 'stork' \\
\hline dark & & cucaracha 'roach'; cuervo 'crow' \\
\hline agile & & ratón 'mouse'; trucha 'trout' \\
\hline elusive & & ratón 'mouse'; trucha 'trout' \\
\hline ugly & & castor 'beaver'; murciélago 'bat' \\
\hline
\end{tabular}

Table 7: Character traits that were mentioned for more than one animal term in the open questionnaire

Furthermore, participants indicated twice that an animal term is not used for women, namely in the case of semental 'stud' and trucha 'trout'. All other animal traits were indicated for only one animal term. It is important to note that some of the animal terms (musaraña 'shrew', perdiz 'partridge') feature in relevant Spanish collocations and are therefore likely to be influenced by their meanings. Accordingly, estar pensando en las musarañas 'thinking about shrews' and estar mirando a las musarañas 'looking at shrews' both express that someone is distracted and not paying attention (scatter-brained, sleepy, pensive; see Table 6). Furthermore, when it comes to perdiz 'partridge', the Spanish expression estar más feliz que una perdiz 'to be happier than a partridge' could be compared to the English expression to be happy as a lark. Additionally, the English equivalent of the Spanish $y$ vivieron felices $y$ comieron perdices 'and they lived happily and ate partridges' is and they lived happily ever after (happy; see Table 6). Lastly, two collocations involving ratón 'mouse' are jugar al gato y al ratón which literally translates to and corresponds to the English to play cat and mouse (agile, quiet, elusive; see Table 6) as well as saber más que los ratones colorados 'to know more than red mice' which corresponds to the English to be sly as a fox (cunning, intelligent; see Table 6).

When comparing the results of this questionnaire with the meanings of the ten animal metaphors that are documented in English but not in Spanish, it is apparent that most animal metaphors convey different meanings in the two languages, as Table 8 indicates. 


\begin{tabular}{|c|c|c|c|}
\hline $\begin{array}{l}\text { Animal } \\
\text { term }\end{array}$ & $\begin{array}{l}\text { English meaning } \\
\text { (dictionaries) }\end{array}$ & Spanish association (questionnaire II) & $\begin{array}{l}\text { (Partial) } \\
\text { match }\end{array}$ \\
\hline quail & young & small; thin; caring; familiar & $x$ \\
\hline shrew & $\begin{array}{l}\text { ill-tempered; malignant; } \\
\text { aggressive; quarrelsome }\end{array}$ & $\begin{array}{l}\text { scatter-brained; quiet; small; sleepy; } \\
\text { pensive }\end{array}$ & $x$ \\
\hline roach & $\begin{array}{l}\text { unpleasant; despicable; } \\
\text { ugly; licentious }\end{array}$ & $\begin{array}{l}\text { despicable; disgusting; bad; dirty; small; } \\
\text { dark; insignificant }\end{array}$ & $\checkmark$ \\
\hline mouse & young & $\begin{array}{l}\text { small; likes cheese; cunning; agile; quiet; } \\
\text { eats little; industrious; elusive; } \\
\text { intelligent }\end{array}$ & $x$ \\
\hline beaver & sexually attractive & big teeth; industrious; ugly; persistent & $x$ \\
\hline stud & $\begin{array}{l}\text { lesbian with a stereotypi- } \\
\text { cally masculine identity } \\
\text { or appearance }\end{array}$ & $\begin{array}{l}\text { not used to refer to women; promiscu- } \\
\text { ous; sexual appetite; reproduces a lot; } \\
\text { sexually potent; sexually active; trans- } \\
\text { sexual; competent; coarse; attractive; } \\
\text { masculine }\end{array}$ & $\checkmark$ \\
\hline trout & ugly; old; ill-tempered & $\begin{array}{l}\text { homosexual; elusive; agile; not used to } \\
\text { refer to women; stupid; industrious }\end{array}$ & $x$ \\
\hline bat & $\begin{array}{l}\text { ugly; promiscuous; disa- } \\
\text { greeable; foolish; prosti- } \\
\text { tute who walks the streets } \\
\text { at night }\end{array}$ & nocturnal; likes the night; ugly & $\checkmark$ \\
\hline crow & ugly; old & $\begin{array}{l}\text { malicious; dark; dressed in black; intelli- } \\
\text { gent; carrion-eating; big nose; afraid of } \\
\text { people; witch; brings bad luck; in low } \\
\text { spirits; cunning; exploitative }\end{array}$ & $x$ \\
\hline partridge & attractive & happy; small & $x$ \\
\hline
\end{tabular}

Table 8: The ten animal terms that are documented in English but not in Spanish ${ }^{11}$

Thus, the Spanish participants' associations with the animals quail, shrew, mouse, beaver, trout, crow, and partridge do not match those documented in English. In fact, in some cases the disparity seems striking: For example, while in English a woman referred to as shrew is considered to be ill-tempered, malignant, aggressive, and quarrelsome, the Spanish associations evoke thoughts of a rather harmless woman (quiet, small, sleepy). Similarly, while the English beaver refers to a sexy woman - a metonymic extension of beaver referring to the female genitals or pubic area due to the supposed similarity in hairiness -, the Spanish equivalent seems to remind the participants of an ugly woman with big teeth. There are, however, three close or partial matches between the two languages. Firstly, a woman referred to as roach is seen as an unpleasant, despicable, ugly, and licentious woman in English, while the Spanish participants associate similar character traits with this animal (despicable, disgusting, bad, dirty). Secondly, a

\footnotetext{
11 The second column gives their respective meaning in English (as found in the dictionaries), the third one their respective associations in Spanish (as indicated by the participants of questionnaire II). The last column indicates whether the meaning of the animal metaphors in the two languages match.
} 
homosexual woman with a stereotypically masculine identity or appearance is referred to as stud in English. Although the Spanish participants do not indicate associations with homosexuality, they do list stereotypically masculine traits, e. g. sexually potent, competent, ${ }^{12}$ coarse, and masculine. Finally, among other things, the English animal term bat refers to an ugly woman or a prostitute who walks the streets at night, which corresponds to the Spanish participants' associations of murciélago with an ugly and nocturnal woman. An interesting finding concerns the participants' English skills. Each of the following character traits - representing a match between the English and the Spanish animal term - was in each case mentioned by one participant with very good English skills: ugly and licentious (cucaracha 'roach'), homosexual (semental 'stud'), ugly and unkind (trucha 'trout'), ugly and old (cuervo 'crow'), and elegant and dolled up (perdiz 'partridge'). This could be a sign of possible L2 lexical inference.

Overall, there does not appear to be a clear correlation between the type of animal and whether or not the Spanish associations correspond to the English meanings of the respective animal metaphors. Thus, the three animals with matches between English and Spanish are one insect (roach) and two mammals (stud, bat), even though a bat is certainly a highly non-prototypical mammal as it is the only mammal capable of flying, which is heavily associated with birds. There are no matches between English and Spanish for the remaining three mammals (shrew, mouse, beaver), any of the birds (quail, crow, partridge) or the fish (trout). Furthermore, when it comes to matches between English and Spanish, it seems not to matter whether the animal is a farm animal/edible animal (stud) or a wild animal/inedible animal (roach, bat). The same seems to be true regarding the participants' degree of insecurity about the possible animal metaphors (see Figure 5).

\section{Discussion}

In this section, the most interesting results and patterns detected in section 4 are discussed in more detail in order to draw both theoretical and methodological conclusions. Firstly, when it comes to the three well-documented Spanish animal metaphors zorra 'vixen', vaca 'cow', and lagarta 'lizard' to refer to certain types of women, it is little surprising that the participants in both questionnaires showed no insecurity about the respective meanings and indicated them in accordance with the respective documented meanings. However, the results of both questionnaires revealed that even well-documented animal metaphors might have more multidimensional meanings than those recorded. Accordingly, while both zorra 'vixen' and lagarta 'lizard' are documented as metaphors for a promiscuous and cunning woman and were indeed rated as such by the participants, they were both indicated to refer to additional types of women. In the Likert scale questionnaire, both animal terms were indicated to refer to a quarrelsome and sexy woman, and in the questionnaire with the open questions, zorra 'vixen' was reported to refer to a bad, malicious, selfish, intelligent, perverse, hurtful, lewd, unscrupulous, and disrespectful woman, and lagarta 'lizard' to a bad, selfish, exploitative, mysterious, unreliable, careerist, false, malicious, deceitful woman who talks behind people's back and is interested in unavailable men. On the one hand, this shows that "[a]nimal metaphors [...] are multi-faceted" (LópezRodríguez 2016: 83) and that personality and character traits consist of more than only one or

${ }^{12}$ For gender stereotypes regarding higher competence in men and lower competence in women, cf. Eckes (2002), Fiske et al. (2002), Fowers/Fowers (2010), and Ellemers (2018), for example. 
a few dimensions (cf. Corr/Poropat 2016: 27). On the other hand, it might suggest that dictionaries tend to display only the most prominent feature(s) of multidimensional personality types, disregarding features that form part of a certain personality type to a lesser degree. Methodologically, the two questionnaire types used in this present study - but especially the open question one - can help uncover the many facets of personality and character traits expressed through animal metaphor as well as provide more detail in this regard compared to dictionaries.

When it comes to the animal terms referring to different types of women that are documented to exist in English but not in Spanish, semental 'stud' is an interesting case. As shown in 4, participants of the Likert scale questionnaire rated this animal term as referring to a promiscuous and sexy woman (see 4.1), while participants of the second questionnaire indicated that this animal term is either not used to refer to women or that they associate it with promiscuity, reproduction, attractiveness, competency, masculinity, transsexuality, coarseness, and sexual appetite, potency, and activity (see 4.2). In English, stud can refer to both a sexually successful, particularly masculine young man and a lesbian who adopts a stereotypically masculine identity or appearance. Overall, the participants seem to associate masculinity as opposed to homosexuality with this animal - even though semental 'stud' is the animal term that has the second highest score for homosexual in the Likert scale questionnaire, after trucha 'trout' in first place. An explanation for the participants' focus on masculinity over female homosexuality could lie in stereotypicality: The stereotypical person of masculine appearance and behaviour, which the animal stud alludes to, tends to be a heterosexual man rather than a homosexual woman. In Spanish, this tendency is intensified further by the fact that semental 'stud' is derived from semen 'semen'.

The animal term that was clearly indicated to be referring to a homosexual woman in both questionnaires is trucha 'trout'. In English, trout is not documented to refer to homosexuality. As mentioned in 4, the general association of that animal with homosexuality in Spanish is likely due to the common usage of trucha 'trout' to refer to a homosexual and effeminate man. This suggestion is supported by the fact that two participants in the second questionnaire indicated that this animal metaphor is only used to refer to men. Fish and seafood are known to serve as source concepts for the metaphorical conceptualization of women and their genitalia, arguably due to the supposed similarity in slipperiness and smell (cf. Allan/Burridge 2006: 195), and that by metonymic extension male homosexuality is associated with femininity (cf. Crespo-Fernández 2015: 174). When it comes to the specific case of trucha 'trout', it has been suggested that its usage as an expression for a homosexual man has been popularized by the Spanish television series Los Serrano in 2003 and that it might be motivated by the association of the rainbow trout with the rainbow flag as an LGBTQ+ symbol (cf. Moscas de Colores 2020). In any case, it seems that in the present study, by a second metonymic extension, male homosexuality provides mental access to female homosexuality and causes the participants to disregard most of the other options - regardless of which questionnaire the participants were presented with.

However, while the participants of both questionnaires indicated that trucha 'trout' refers to a homosexual woman, this trend was much higher in the Likert scale questionnaire compared to the open questions - and this is not only the case for trucha 'trout'. Overall, the results reveal a clear discrepancy when it comes to the participants' insecurities about the animal metaphors. 
When presented with possible character traits, it seems that the participants are more inclined to accept one or multiple options. On the contrary, when required to fill in an empty text box, it appears the participants are generally more unsure about the potential meanings of the animal metaphors. When comparing the amount of times that the participants indicated no sé 'I don't know' out of all data points, it is $7.39 \%$ in the Likert scale questionnaire and $39.62 \%$ in the questionnaire with the open questions. Of course, the approach using the Likert scales provides more quantifiable and comparable data and less blank values, but the open questions approach offers a wider picture of the multidimensionality of personality types and appears to sway the participants less. Something that both methodologies have in common, though, is that they highlight how multifaceted the associations conveyed in animal metaphors are and how difficult it is to narrow them down for concise dictionary entries.

All in all, this present study found that the animal metaphors that are documented to exist in English but not in Spanish as referring to certain types of women are for the most part not meaningful to the Spanish participants (see Figures 3 and 5) and do, to a large extent, not match with the English meaning when translated into Spanish. There are some partial or close matches (roach, stud, bat) that seem to largely convey the same meaning in both languages, but the remaining animal metaphors do not appear to correspond. However, from a broader perspective, there is some congruence between the English and Spanish animal metaphors in that - specifically in the questionnaire employing open questions - animals that are associated in English with what is stereotypically considered positive features in women, such as small size, young age, inferiority (cf. López-Rodríguez 2009: 95), tend to also be considered positively in Spanish; and vice versa in the case of negative associations, such as large size, old age, strength, promiscuity. Accordingly, mouse, quail, and partridge seem to convey positive and crow negative connotations in both English and Spanish.

Another important finding concerns the fact that the big majority of the tested animal metaphors refers to women pejoratively. This is the case for the documented and undocumented animal terms as well as for both types of questionnaires (Likert scales and open questions). Of course, for the well-documented animal metaphors zorra 'vixen', vaca 'cow', and lagarta 'lizard' this is to be expected as their associations are known to be negative (promiscuity, obesity, ugliness). When it comes to the undocumented animal metaphors, though, there is a clear pattern in the Likert scale questionnaire to predominantly associate various animal terms with ugliness: Out of the twelve undocumented animal terms (ten documented in English, two undocumented in English and Spanish), the participants rate ugliness as the number one trait in eight animals and as the number two trait in two animals. This applies for both 'prototypically' unsightly animals like roach, beaver, and bat, as well as animals that are not generally tied to unsightliness such as quail, stork, and mouse. It seems then that, first and foremost, novel animal metaphors provide mental access to ugliness, mostly regardless of the animal species. This might be due to the fact that ugliness is a concrete physical and visual factor which tends to be easier to grasp than abstract character traits denoting a woman's personality. In other words, ugliness might be the default association of novel animal metaphors applied to women, while other associations (e. g. kindness, quarrelsomeness, homosexuality) might be less accessible and establish with increasing metaphor conventionality. Additionally, as suggested by the Great Chain of Being (see 2.2), animal metaphors are in any case more likely to link women to negative features. 
Accordingly, in the second questionnaire (open questions), seven out of the twelve undocumented animal metaphors are endowed by the participants with rather negative traits (e. g. despicable, promiscuous, malicious, scatter-brained), while four are generally rated as positive (ratón 'mouse', cigüeña 'stork', codorniz 'quail', perdiz 'partridge') and one as neutral (trucha 'trout'). Similarly, in the Likert scale questionnaire the character traits that were most often indicated to be associated with the animal terms are generally negative (ugly, promiscuous, quarrelsome, fat), with the positive ones featuring less (kind, young, good-looking, sexy) (see Table 4).

While some results of the present study conform to findings of previous studies, others do not. For example, as argued by López-Rodríguez (2009: 95), it seems to be the case that names of wild animals - as opposed to pets and farmyard animals - are consistently endowed with negative connotations. This claim can be substantiated when looking at the results from the Likert scales questionnaire, but not in its entirety when looking at the answers to the open questions. In the former case, the highest-rated character trait of each animal is one that conveys negative connotations, with ugly as the most common one. However, it must be mentioned at this point that, in the Likert scale questionnaire, the highest-rated character trait of all 15 animal terms (including farmyard and edible animals), except for perdiz 'partridge', is a negative one. This, then, seems to partially contradict López-Rodríguez' (2009) overall findings. Additionally, when it comes to the open questions, the results do not fully support her claims either as all animal terms are indicated as having mostly negative character traits, with the exception of the two edible animals codorniz 'quail' (small) and perdiz 'partridge' (happy) as well as the two inedible wild animals ratón 'mouse' (small) and cigüeña 'stork' (tall). Again, it seems that the methodology chosen in this present study involving questionnaires employing Likert scales and open questions tends to yield results that differ significantly from dictionary-based approaches.

An interesting observation from this present study concerns one participant's associations with the animal term murciélago 'bat' in the second questionnaire (open questions). When presented with this animal metaphor and asked about the type of woman it could refer to, the answer was the following:

Right now, it would be a woman who can or in fact does transmit diseases and who is not careful about it. [Spanish original: 'Ahora mismo sería una mujer que puede o de hecho transmite enfermedades y que no tiene cuidado con ello.']

(female participant, 24 years old, intermediate English skills, questionnaire with open questions)

The participant is, of course, alluding to the global COVID-19 pandemic that began in late 2019 and is believed to have spread from bats to humans. The participant's association of a woman referred to as bat with the pandemic could be an indication as to how influential current affairs and developments in our environments can be on our understanding of animal metaphors. However, considering the study was conducted at the height of the pandemic but only one participant addressed it, it shows how stable people's associations with animal species tend to be: "In our metaphorical language [animals] stand for a limited number of slots, that is to say features which can be projected upon the target. They are pre-established by a long tradition" (Bisschops 2019: 1). 


\section{Conclusion}

It has been shown in this paper that animal metaphors for different types of women that are documented to exist in English but not in Spanish convey, to a large extent, different meanings in the two languages when translated into Spanish and judged by native speakers. This appears to be the case regardless of the type of animal (mammal vs. bird etc.; farm/edible vs. wild/inedible animal). Additionally, it seems that novel animal metaphors denoting women are by default interpreted as referring to ugliness, regardless of whether the animal, i. e. the source concept, is generally considered an unsightly animal. This appears to be a new finding and it would be interesting to test if it holds true when investigating a larger amount of novel animal metaphors.

Furthermore, while the well-documented Spanish animal metaphors revealed no insecurities among the participants regarding their meaning, there were significant insecurities in several cases of the undocumented metaphors. However, since the documented English animal metaphors were chosen for this study based on a dictionary search, it would be interesting to investigate how well-established they really are. It is possible that English native speakers would in fact associate some of the animal terms with different character traits than those documented in the dictionaries consulted for the present study, revealing thus more similarities between Spanish and English speakers' associations. Additionally, it seems likely that the ten Likert scales in the first questionnaire were not numerous enough for the participants to precisely indicate their associations with the different animal terms as personalities are extremely multidimensional - something that the answers provided in the second questionnaire employing open questions highlighted. Such methodological refinements, then, could yield interesting divergent results. In any case, the combination of the two types of questionnaires (Likert scales and open questions) seems to be a fruitful design to approach novel animal metaphors multi-methodologically. Furthermore, instead of focussing on animal terms, follow-up studies could employ animal pictures to be presented to Spanish and English native speakers and have them assign the animals to a variety of character traits. This would shed light on potential differences between an animal concept and the respective animal term. Moreover, as opposed to investigating one or two languages, future research could focus on large-scale cross-cultural studies on novel animal metaphors, incorporating a variety of different languages and cultures.

\section{References}

Ahrens, Kathleen (2010): "Mapping principles for conceptual metaphors". In: Low, Graham et al. (eds.): Researching and applying metaphor in the real world. Amsterdam/Philadelphia, Benjamins: 185-208. doi: 10.1075/hcp.26.12ahr.

Ahrens, Kathleen et al. (2007): "Functional MRI of conventional and anomalous metaphors in Mandarin Chinese". Brain and Language 100: 163-171. doi: 10.1016/j.band1.2005.10.004. Ahrens, Kathleen/Say, Alicia L. T. (1999): "Mapping image-schemas and translating metaphors". The 13th Pacific Asia conference on language, information and computation. Proceedings. February 10-11, 1999, Taiwan, R. O. C: 95-102.

Allan, Keith/Burridge, Kate (2006): Forbidden words. Taboo and the censoring of language. Cambridge: Cambridge University Press. doi: 10.1017/CBO9780511617881. 
Ayto, John/Simpson, John (2013): The Oxford dictionary of modern slang. $2^{\text {nd }}$ edition. Oxford: Oxford University Press. doi: 10.1093/acref/9780199543700.001.0001.

Bazzi, Samia (2014): "Foreign metaphors and Arabic translation. An empirical study in journalistic translation practice”. Journal of Language and Politics 13/1: 120-151. doi: 10.1075/jlp.13.1.06baz.

Bisschops, Ralph A. (2019): "Pursuing a diachronic approach to metaphor. Metaphorical precedents and emblems". In: Barcelona Sánchez, Antonio (ed.): Spanish Cognitive Linguistics Association (AELCO). 11th international conference of the Spanish Cognitive Linguistics Association (AELCO), 17th-19th October 2018. Córdoba, Universidad Nacional de Córdoba: $1-3$.

Bock, Jarrod/Burkley, Melissa (2018): "On the prowl. Examining the impact of men-as-predators and women-as-prey metaphors on attitudes that perpetuate sexual violence". Sex Roles 80/5: 262-276. doi: 10.1007/s11199-018-0929-1.

Cameron, Lynne/Deignan, Alice (2006): “The emergence of metaphor in discourse". Applied Linguistics 27/4: 671-690. doi:10.1093/applin/aml032.

Corr, Philip J./Poropat, Arthur E. (2016): "Personality assessment and theory". In: Kumar, Updesh (ed.): The Wiley handbook of personality assessment. Hoboken, Wiley \& Sons: 19-30. doi: 10.1002/9781119173489.ch2.

Crespo-Fernández, Eliecer (2015): Sex in language. Euphemistic and dysphemistic metaphors in internet forums. London: Bloomsbury Academic.

Cruz Cabanillas, Isabel/Tejedor Martínez, Cristina (2002a): “The HORSE family. On the evolution of the field and its metaphorization process". In: Díaz Vera, Javier E. (ed.): A changing world of words. Studies in English historical lexicography, lexicology and semantics. Amsterdam, Rodopi: 229-254.

Cruz Cabanillas, Isabel/Tejedor Martínez, Cristina (2002b): "Women as evil. Animal metaphors referred to women". In: Moskowich-Spiegel, Isabel et al. (eds.): Re-interpretations of English. Essays on language, linguistics and philology (I). A Coruña, Universidade da Coruña: 9-27.

Cruz Cabanillas, Isabel/Tejedor Martínez, Cristina (2006): “Chicken or hen? Domestic fowl metaphors denoting human beings". Studia Anglica Posnaniensia 42: 337-354.

Deignan, Alice (2010): “The cognitive view of metaphor. Conceptual metaphor theory". In: Cameron, Lynne/Maslen, Robert (eds.): Metaphor Analysis. Research practice in Applied Linguistics, Social Sciences and the Humanities. London, Equinox: 44-56.

Diccionario de la lengua española de la Real Academia Española (DRAE). dle.rae.es [24.03.2021].

Dobrotă, Corina (2017): “Aspects of zoonym translation in the American business jargon". Translation Studies. Retrospective and Prospective Views 20/2: 43-54.

Duan, Huiqiong/Cui, Wei Wie/Gao, Yi Dan (2014): "Cultural metaphor and translation strategies in English and Chinese animal idioms". Journal of Language Teaching and Research 5/6: 1292-1300. doi: 10.4304/jltr.5.6.1292-1300.

Echevarría Isusquiza, Isabel (2003): “Acerca del vocabulario español de la animalización humana". Círculo de lingüística aplicada a la comunicación 15.

Eckes, Thomas (2002): "Paternalistic and envious gender stereotypes. Testing predictions from the stereotype content model". Sex Roles 47/3: 99-114. doi: 10.1023/A:1021020920715. 
Eggertsson, Gunnar T./Forceville, Charles (2009): "Multimodal expressions of the HUMAN VICTIM IS ANIMAL metaphor in horror films”. In: Forceville, Charles/Urios-Aparisi, Eduardo (eds.): Multimodal metaphor. Berlin/New York, Mouton de Gruyter: 429-449. doi:10.1515/9783110215366.7.429.

Ellemers, Naomi (2018): “Gender stereotypes”. Annual Review of Psychology 69/1: 275-298. doi: 10.1146/annurev-psych-122216-011719.

Evans, Vyvyan/Green, Melanie (2006): Cognitive Linguistics. An introduction. Edinburgh: Edinburgh University Press.

Fernández Fontecha, Almudena/Jiménez Catalán, Rosa M. (2003): "Semantic derogation in animal metaphor. A contrastive-cognitive analysis of two male/female examples in English and Spanish". Journal of Pragmatics 35/5: 771-797. doi: 10.1016/S0378-2166(02)00127-3.

Fernández Martín, Carmen (2011): "Comparing sexist expressions in English and Spanish. (De)-constructing sexism though language". ES. Revista de Filología Inglesa 32: 67-90.

Fiske, Susan T. et al. (2002): “A model of (often mixed) stereotype content. Competence and warmth respectively follow from perceived status and competition". Journal of Personality and Social Psychology 82/6: 878-902. doi: 10.1037//0022-3514.82.6.878.

Forceville, Charles (2006): "Non-verbal and multimodal metaphor in a cognitivist framework. Agendas for research". In: Kristiansen, Gitte et al. (eds.): Cognitive Linguistics. Current applications and future perspectives. Berlin/New York, de Gruyter: 379-402. doi: 10.1515/9783110215366.1.19.

Fowers, Alyssa F./Fowers, Blaine J. (2010): "Social dominance and sexual self-schema as moderators of sexist reactions to female subtypes". Sex Roles 62/7: 468-480. doi: 10.1007/s11199-009-9607-7.

Goatly, Andrew (2006): "Humans, animals, and metaphors". Society \& Animals 14/1: 15-37. doi: $10.1163 / 156853006776137131$.

Górecka-Smolińska, Malgorzata/Kleparski, Grzegorz A. (2011): "Human picturing of birds. The case study of zoosemic developments in the category female domesticated birds". SKASE Journal of Theoretical Linguistics 8/2: 31-54.

Haslam, Nick/Loughnan, Steve/Sun, Pamela (2011): "Beastly. What makes animal metaphors offensive?". Journal of Language and Social Psychology 30/3: 311-325. doi: 10.1177/0261927X11407168.

Hermanson, Eric A./Plessis, Jacobus A. du (1997): "The conceptual metaphor 'people are animals' in Zulu". South African Journal of African Languages 17/2: 49-56. doi: 10.1080/02572117.1997.10587161.

Hines, Caitlin (1996): "She-wolves, tigresses, and morphosemantics". In: Warner, Natasha et al. (eds.): Gender and belief systems. Proceedings of the fourth Berkeley women and language conference, April 19, 20, and 21. Berkeley, University of California: 303-311.

Hines, Caitlin (1999a): "Foxy chicks and Playboy bunnies. A case study in metaphorical lexicalization”. In: Hiraga, Masako/Sinha, Chris/Wilcox, Sherman (eds.): Cultural, psychological, and typological issues in Cognitive Linguistics. Selected papers of the bi-annual ICLA meeting in Albuquerque, July 1995. Amsterdam/Philadelphia, Benjamins: 9-24. doi: 10.1075/cilt.152.04hin. 
Hines, Caitlin (1999b): "Rebaking the pie. The woman as dessert metaphor". In: Bucholtz, Mary/Liang, A. C./Sutton, Laurel A. (eds.): Reinventing identities. The gendered self in discourse. Oxford: Oxford University Press: 145-162.

Hsieh, Shelley C. (2004): "The corpora of Mandarin Chinese and German animal fixed expressions. A cognitive semantic application". University Centre for Computer Corpus Research on Language Technical Papers 18: 27-35.

Hsieh, Shelley C. (2006): “A corpus-based study on animal expressions in Mandarin Chinese and German". Journal of Pragmatics 38/12: 2206-2222. doi: 10.1016/ j.pragma.2006.08.007.

Hsieh, Shelley C. (2009): Embodiment in languages (1). Human, animal and plant expressions. Taipei: Bookman.

Jiang, Feng/Wen, Xu (2014): “A comparative study of English and Chinese animal 'rooster' metaphor from the cognitive perspective". Canadian Social Science 10/4: 66-70.

Kiełtyka, Robert (2005): "Zoosemic terms denoting female human beings. Semantic derogation of women revisited". Studia Anglica Posnaniensia 41: 167-186.

Kiełtyka, Robert/Kleparski, Grzegorz A. (2005): "The ups and downs of the Great Chain of Being. The case of canine zoosemy in the history of English". SKASE Journal of Theoretical Linguistics 2: 22-41.

Kiełtyka, Robert/Kleparski, Grzegorz A. (2007): “On the Indo-European nature of non-IndoEuropean animal metaphor. The case of Chinese zoosemy”. Studia Anglica Resoviensia 4/47: 88-99.

Kilyeni, Annamaria/Silaški, Nadežda (2014): "Beauty and the Beast from a cognitive linguistic perspective. Animal metaphors for women in Serbian and Romanian". Gender Studies 13/1: 163-178. doi: 10.1515/genst-2015-0012.

Kobia, John M. (2016): “A conceptual metaphorical analysis of Swahili proverbs with reference to chicken metaphor". International Journal of Education and Research 4/2: 217-228.

Kövecses, Zoltán (1986): Metaphors of anger, pride and love. A lexical approach to the structure of concepts. Amsterdam: Benjamins. doi: 10.1075/pb.vii.8.

Kövecses, Zoltán (2000): Metaphor and emotion. Language, culture, and body in human feeling. Cambridge: Cambridge University Press.

Kövecses, Zoltán (2005): Metaphor in culture. Universality and variation. Cambridge: Cambridge University Press. doi: 10.1017/CBO9780511614408.

Kövecses, Zoltán (2008): "Universality and variation in the use of metaphor". In: Johannesson, Nils-Lennart/Minugh, David C. (eds.): Selected papers from the 2006 and 2007 Stockholm metaphor festivals. Stockholm, Acta Universitatis Stockholmiensis: 55-74.

Kövecses, Zoltán (2010): Metaphor. A practical introduction. $2^{\text {nd }}$ edition. Oxford: Oxford University Press.

Lakoff, George/Johnson, Mark (1980): Metaphors we live by. Chicago: University of Chicago Press.

Lakoff, George/Johnson, Mark (1999): Philosophy in the flesh. The embodied mind and its challenge to western thought. New York: Basic Books.

Lakoff, George/Turner, Mark (1989): More than cool reason. A field guide to poetic metaphor. Chicago: University of Chicago Press. 
López-Rodríguez, Irene (2007a): "From the Bible to Cosmopolitan. The socialization of women through the WOMAN AS CHICKEN metaphor". Revista de Letras 6/2: 129-153.

López-Rodríguez, Irene (2007b): "The representation of women in teenage and women's magazines. Recurring metaphors in English". Estudios Ingleses de la Universidad Complutense 15: $15-42$.

López-Rodríguez, Irene (2009): “Of women, bitches, chickens and vixens. Animal metaphors for women in English and Spanish". Cultura, lenguaje y representación/Culture, language and representation 7: 77-100.

López-Rodríguez, Irene (2014): "Reinforcing the domestic role of women through the woman as chicken metaphor. A diachronic study". BABEL-AFIAL 23: 137-184.

López-Rodríguez, Irene (2016): "Feeding women with animal metaphors that promote eating disorders in the written media". Linguistik Online 75/1: 71-101. doi: 10.13092/lo.75.2517.

Miri, Marveh/Soori, Afshin (2015): “A contrastive analysis of animal metaphor in English and Persian". Advances in Language and Literary Studies 6/2: 160-162. doi: 10.7575/aiac.alls.v.6n.2p.160.

Molina Plaza, S. (2008). "De mujeres, gatos y otros animales. Paremias y locuciones metafóricas y metonímicas en inglés y español". Paremia 17: 91-99.

Moliner, María (2008): Diccionario de uso del español. $3^{\text {rd }}$ edition. Madrid: Gredos.

Moscas de Colores (2020): Trucha. Diccionario Gay (España). moscasdecolores.com/es/seriegay-slang/trucha-diccionario-gay-espana/ [14/12/2020].

Nesi, Hilary (1995): "A modern bestiary. A contrastive study of the figurative meanings of animal terms". ELT Journal 49/3: 272-278. doi: 10.1093/elt/49.3.272.

Neumann, Christoph (2001): "Is metaphor universal? Cross-language evidence from German and Japanese". Metaphor and Symbol 16/1: 123-142. doi: 10.1080/10926488.2001.9678890.

Nilsen, Alleen P. (1996): "Of ladybugs and billy goats. What animal species names tell about human perceptions of gender". Metaphor and Symbolic Activity 11/4: 257-271. doi: 10.1207/s15327868ms1104_2.

Oxford English Dictionary (OED). oed.com/ [25.03.2021].

Partridge, Eric (2013): The new Partridge dictionary of slang and unconventional English. $2^{\text {nd }}$ edition. London: Routledge. doi: 10.4324/9781315672229.

Reza Talebinejad, Mohammad/Vahid Dastjerdi, Hossein (2005): "A cross-cultural study of animal metaphors. When owls are not wise!”. Metaphor and Symbol 20/2: 133-150. doi: $10.1207 / \mathrm{s} 15327868 \mathrm{~ms} 2002 \_3$.

Rodríguez González, Félix (2011): Diccionario del sexo y el erotismo. Madrid: Alianza Editorial.

Sanz Martin, Blanca E. (2015): "Las metáforas zoomorfas desde el punto de vista cognitivo". Íkala. Revista de Lenguaje y Cultura 20/3: 361-383. doi: 10.17533/udea.ikala.v20n3a06.

Silaški, Nadežda (2013): “Animal metaphors and semantic derogation. Do women think differently from men?”. Gender Studies 12: 319-332. doi: 10.2478/genst-2013-0020.

Sommer, Robert/Sommer, Barbara A. (2011): “Zoomorphy. Animal metaphors for human personality". Anthrozoös 24/3: 237-248. doi: 10.2752/175303711X13045914865024.

Thornton, Freda J. (1988): A classification of the semantic field good and evil in the vocabulary of English. PhD thesis. Glasgow: University of Glasgow. 
Tipler, Caroline N./Ruscher, Janet B. (2019): "Dehumanizing representations of women. The shaping of hostile sexist attitudes through animalistic metaphors". Journal of Gender Studies 28/1: 109-118. doi: 10.1080/09589236.2017.1411790.

Toriyama, Sekien/Yoda, Hiroko/Alt, Matt (2016): Japandemonium illustrated. The yokai encyclopedias of Toriyama Sekien. Mineola: Dover Publications, Inc.

Wang, Chongying/Dowker, Ann (2008): "Interpretation of animal metaphors. Evidence from Chinese and English children and adults". In: Marinis, Theodoros/Papangeli, Angeliki/Stojanovik, Vesna (eds.): Proceedings of the 2007 child language seminar. $30^{\text {th }}$ anniversary. Reading, University of Reading: 216-225.

Waśniewska, Małgorzata/Kudin, Mykyta (2018): "The universality and variety of the women are animals conceptual metaphor across European languages". In: Gunesch, Konrad/Lytovka, Olena/Tryniecka, Aleksandra (eds.): Crossing borders in gender and culture. Newcastle upon Tyne, Cambridge Scholars Publishing: 94-117.

Wei, Lixia (2011): “A corpus-based study on A MAN IS A LION in Mandarin Chinese and British English". 3L. Language, Linguistics and Literature. The Southeast Asian Journal of English Language Studies 17/2: 1-10.

Wei, Lixia/Wong, Bee E. (2012): “A corpus-based study on snake metaphors in Mandarin Chinese and British English". GEMA Online Journal of Language Studies 12/1: 311-324.

Yu, Ning (2008): "Metaphor from Body and Culture". In: Gibbs, Raymond W. Jr. (ed.): The Cambridge handbook of metaphor and thought. New York, Cambridge University Press: 247-261. doi: 10.1017/CBO9780511816802.016. 